IZA DP No. 4778

What's the Difference?! Gender, Personality, and the Propensity to Start a Business

Marina Furdas

Karsten Kohn

February 2010 


\title{
What's the Difference?! Gender, Personality, and the Propensity to Start a Business
}

\author{
Marina Furdas \\ Albert-Ludwigs-University Freiburg \\ Karsten Kohn \\ KfW Frankfurt \\ and IZA
Discussion Paper No. 4778
February 2010 \\ IZA \\ P.O. Box 7240 \\ 53072 Bonn \\ Germany \\ Phone: +49-228-3894-0 \\ Fax: +49-228-3894-180 \\ E-mail: iza@iza.org
}

Any opinions expressed here are those of the author(s) and not those of IZA. Research published in this series may include views on policy, but the institute itself takes no institutional policy positions.

The Institute for the Study of Labor (IZA) in Bonn is a local and virtual international research center and a place of communication between science, politics and business. IZA is an independent nonprofit organization supported by Deutsche Post Foundation. The center is associated with the University of Bonn and offers a stimulating research environment through its international network, workshops and conferences, data service, project support, research visits and doctoral program. IZA engages in (i) original and internationally competitive research in all fields of labor economics, (ii) development of policy concepts, and (iii) dissemination of research results and concepts to the interested public.

IZA Discussion Papers often represent preliminary work and are circulated to encourage discussion. Citation of such a paper should account for its provisional character. A revised version may be available directly from the author. 
IZA Discussion Paper No. 4778

February 2010

\section{ABSTRACT \\ What's the Difference?! \\ Gender, Personality, and the Propensity to Start a Business}

Women start fewer businesses than men. The start-up rate among women in Germany falls short of males' start-up rate by one third. We scrutinize this gender gap using individual-level data from the KfW Start-up Monitor, a large-scale population survey on start-up activity in Germany. As a unique feature, the data combine socio-demographic characteristics, entrepreneurship-related attitudes, and general personality traits of both business starters and non-starters. Estimating binary choice models and employing decomposition techniques, we find that gender differences in socio-demographics alone would even be in favor of higher start-up rates among women, while the distribution of personality traits is less favorable for business start-ups among women and explains about one third of the entire gender difference. Most substantially, men opt for a start-up more often even given identical human capital and related endowments. Qualificational policies targeted towards higher educational attainments of potential entrepreneurs do thus not suffice to increase the number of female business starters.

JEL Classification: J16, L26, M13

Keywords: entrepreneurship, gender difference, start-up propensity, decomposition analysis, KfW Start-up Monitor, Germany

Corresponding author:

Karsten Kohn

KfW

Department of Economics

Palmengartenstr. 5-9

60325 Frankfurt am Main

Germany

E-mail: karsten.kohn@kfw.de

\footnotetext{
* Arguments in this article express personal views of the authors and do not necessarily reflect those of $\mathrm{KfW}$. We thank Bernd Fitzenberger, Hannes Spengler, Katrin Ullrich, and participants of the G-Forum 2008 conference, IECER 2009, and the $11^{\text {th }}$ ZEW Summer Workshop for Young Economists 2009 for fruitful discussions. Marie-Lena Haberstroh provided excellent research assistance. Remaining errors are our sole responsibility.
} 


\section{Introduction}

It is a well-known fact that women start fewer businesses than men. Across industrialized countries, one male self-employed on average comes along with merely 0.64 females. This observation also holds for Germany, where the self-employment rates among men and women in the year 2007 were $13.4 \%$ and 8.6\%, respectively (BMWAÖ, 2008). In the Global Entrepreneurship Monitor (GEM; Sternberg et al., 2007), the share of women among nascent and young entrepreneurs varies considerably across countries. However, entrepreneurial activity rates in all countries are higher for men than for women. In Germany, for instance, the respective rates in the year 2006 were 2.6\% among females and 5.8\% among males (Allen et al., 2007). Similar gender differences are observed in the KfW Start-up Monitor for the year 2007, which reports gender-specific start-up rates of $1.3 \%$ among females and $2.1 \%$ among males (Kohn and Spengler, 2008b).

The individual decision to start a business is influenced by the personality of the (potential) entrepreneur and the start-up environment. While the start-up environment captures, e.g., current economic and political conditions or regional specifics, the concept of personality comprises 'hard' factors like socio-demographic characteristics, as well as 'soft' factors such as personality traits, abilities, attitudes, and perceptions. This bundle of determinants can be expected to exert different impacts on the start-up decisions of men and women.

Gender differences in start-up activity can be analyzed by means of econometric methods based on large-scale individual-level data (de Bruin et al., 2006, 2007). Langowitz and Minniti (2007), for instance, use GEM data to estimate the effects of individual characteristics on the start-up decisions of men and women. Comparable studies for Germany either use regionally selective data—such as the Regional Entrepreneurship Monitor (Wagner, 2007)— or focus on self-employment stock rather than start-ups (e.g., Leicht and Lauxen-Ulbrich, 2005).

Yet most existing studies do not assess the relative importance of different effects for explaining observed gender differences in start-up intensity. Is the lower entrepreneurial activity of women due to a smaller human capital endowment resulting, e.g., from discontinued employment histories or from a lower education? Or does it result from differences in behavior and attitudes beyond observable characteristics? How much of the difference is due to dissimilar personality traits? What is the impact of men and women perceiving the odds of a start-up differently? How much of the overall gender difference in start-up intensity can be explained by models using representative individual-level data? 
In light of these questions, our paper extends upon the existing literature in three main dimensions. First, we use individual-level data from the KfW Start-up Monitor, a large-scale population survey on start-up activities in Germany. The database is representative for the entire population in Germany and offers a large number of entrepreneurship-related variables for both business starters and a comparison group of non-starters. Second, we distinguish the effects of standard socio-demographic characteristics—such as education, age, or household composition—and general 'soft' personality traits for explaining the gender difference in start-up rates. This is important as general personality traits such as risk aversion, creativity, need for achievement, openness to change, and persuasiveness, help explaining the individual start-up decision while using information on persons' attitudes towards entrepreneurship as in related studies is not economically reasonable. Third, and most importantly, we assess the relative contributions of socio-demographics and personality characteristics by means of decomposition techniques. As a methodological contribution, we employ a technique adapted to the non-linear case of binary choice models in a way similar to Fairlie (2005), but construct more meaningful counterfactuals using Mahalanobis distance matching.

Our results show that gender differences in socio-demographics alone would even be in favor of higher start-up rates among women, while the distribution of personality traits is less favorable for business start-ups among women and explains about one third of the entire gender difference. Differences in unobserved characteristics again work in the direction of a lower gender difference. Most substantially, men opt for a start-up more often even given identical endowments with human capital and related characteristics.

The paper is organized as follows. Section 2 briefly reviews related theoretical and empirical evidence on the determinants of gender differences in start-up activity. We focus on the impacts of socio-demographics, personality traits and entrepreneurial attitudes, and on their relative importance. Our empirical investigation in section 3 comprises the introduction of the KfW Start-up Monitor data, descriptive and regression evidence on gender-specific start-up decisions, and the decomposition analysis of start-up differences. Section 4 offers concluding remarks.

\section{Related Literature and Research Hypotheses}

Since the early study of Schwartz (1976) a broad literature on the specifics of female entrepreneurs and gender differences in entrepreneurship has evolved. ${ }^{1}$ The start-up decision

\footnotetext{
${ }^{1}$ See the survey articles of Brush (1992, 2006), Carter, Anderson, and Shaw (2001), Carter and Shaw (2006) and Greene et al. (2003), as well as the collected volumes of Leicht and Welter (2004) and KfW Bankengruppe (2004) for Germany.
} 
of both women and men is usually understood as resulting from a cognitive individual choice-expected utility of becoming an entrepreneur must be higher than the expected utility derived from alternative occupations (Krueger et al., 2000). The choice is framed by a bundle of individual and environmental influences. Determinants at the macro level capture, e.g., current economic and political conditions or regional specifics. At the micro level, the concept of personality comprises 'hard' factors like socio-demographic characteristics, as well as 'soft' factors such as personality traits, abilities, attitudes, and perceptions. ${ }^{2}$ In this regard, gender differences in start-up decisions can result from different framing situations. On the one hand, women and men might have different characteristics which are relevant to the startup decision-women might, e.g., be less educated then men. On the other hand, those characteristics might have different impacts on the decisions of women and men-for example, a university degree might increase the start-up propensity of women to a higher degree as the propensity of men. Finally, women and men might make different decisions even in identical situations. ${ }^{3}$

Empirical research on gender differences in entrepreneurship uses a broad range of methods (de Bruin et al., 2007). Microeconometric studies estimate determinants of the start-up decision based on large micro-level data. When gender is controlled for, the partial effect of being female turns out negative across different countries and different data sets. ${ }^{4}$ The ceteris paribus effect for women resulting from more flexible, gender-specific estimates is also negative. ${ }^{5}$ Moreover, separate analyses for men and women allow for distinctive determinants of the start-up decision. The following paragraphs briefly review existing evidence on genderspecifics in socio-demographic characteristics and personality traits in order to motivate our empirical investigation.

\subsection{Start-Up Propensity, Gender, and Socio-Demographic Characteristics}

Resource-oriented approaches emphasize the importance of financial, human, and social capital for individual start-up decisions (Cooper et al., 1994). Crucial human capital components include education, age, and professional experience. ${ }^{6}$

\footnotetext{
${ }^{2}$ For example, Cooper (1981) differentiates three broad categories of determinants: 'antecedent influences' comprising demographic and personal characteristics of the (potential) entrepreneur; 'incubator organization', which captures employment status and establishment specifics in the pre-decision situation; and 'environmental factors' comprising regulatory framework and economic conditions. At the individual level, Arenius and Minniti (2005) distinguish ‘demographic and economic characteristics' and 'perceptual variables'.

${ }^{3}$ Compare, e.g., Jungbauer-Gans (1993), McManus (2001), and Harrison and Mason (2007).

${ }^{4}$ Compare, e.g., Blanchflower and Oswald (1998), Evans and Leighton (1989), Arenius and Minniti (2005), and Kohn and Spengler (2008b) for Germany.

${ }^{5}$ See, e.g., Langowitz and Minniti (2007) and Wagner (2007).

${ }^{6}$ See Becker (1964) for the merits of general and specific human capital.
} 
From a theoretical point of view, the effect of education on the individual propensity to start a business is ambiguous. On the one hand, higher education is associated with better opportunities in dependent employment, and thus with higher opportunity costs of a start-up. On the other hand, self-employment requires particular commercial and/or technical knowledge, which would give an advantage to higher-skilled persons. Empirical studies often find a positive effect of education on the start-up propensity of both men and women. ${ }^{7}$ Compared to men, women used to have lower formal qualifications in former decades. Yet differences have flattened among recent cohorts. As Leicht et al. (2004) note, the increase in female self-employment in Germany in the 1990's is, to a large extent, due to an increase of female university graduates. ${ }^{8}$

Regarding the impact of age on entrepreneurial propensity, there are also countervailing effects. First, the accumulation of human and financial capital increases over the life cycle, rendering a start-up more likely. Second, increasing private and job-related commitment as well as shorter lifespan decreases the propensity to venture upon the risky and long-termoriented investment of a start-up. Most empirical studies depict an inverted U-shape impact of age-among both men and women, middle-aged persons show the highest start-up rates. ${ }^{9}$ When comparing the age effects for men and women, Wagner (2007) finds no significant differences. However, the relative importance of the above channels is likely to differ. For example, the negative impact of increasing family-related commitment on the individual startup propensity might predominate among women.

Professional experience is closely related to age and qualification. Its overall effect on individual start-up propensity is also ambiguous a priori, while empirical evidence suggests a concave impact (Fischer et al., 1993; Jungbauer-Gans, 1993). Compared to men, women have less professional experience due to maternity leave spells, more frequent part-time work, and resulting discontinued employment histories. More generally, the employment status is pivotal to the start-up decision (Blanchflower and Oswald, 1998). Unemployed persons as well as persons from out of the labor force have lower opportunity costs of a start-up than employed persons and are thus more likely to become self-employed. ${ }^{10}$ Persons who have already experienced self-employment in the past are also more likely to set up another business as a

\footnotetext{
7 Compare, e.g., Dolinsky et al. (1993) and Kohn and Spengler (2008b). There is some variation across countries, though. See Lohmann (2001) and Strohmeyer (2004) for comparative international evidence.

${ }^{8}$ Some international studies even note higher educational attainments of female entrepreneurs as compared to their male counterparts; see, e.g., Zapalska (1997) and Cowling and Taylor (2001).

${ }^{9}$ See, e.g., Bönte et al., (2007), Gottschalk and Theuer (2008), Kohn and Spengler (2008c), Lévesque and Minniti (2006), and van Praag and Booij (2003).

${ }^{10}$ For empirical evidence from Germany see Niefert (2010).
} 
serial entrepreneur or restarter (Metzger, 2006). Both the labor force participation rate and the share of self-employment are substantially lower among females than among males.

Along these lines, gender differences in human capital—such as different professional experience-imply different start-up propensities. However, even with identical human capital endowment, women may be expected to use this capital differently in the process of identifying and exploiting entrepreneurial opportunities (DeTienne and Chandler, 2007).

Different employment histories and comparative advantages give rise to gender-specific segregation in the labor market. 'Female occupations' — for instance secretary jobs—might be associated with less opportunities for a start-up than 'male occupations', e.g., in handicrafts. This has been confirmed by a number of empirical studies. ${ }^{11}$ Professional segregation is also related to socialization and role models in society (Lauxen-Ulbrich and Leicht, 2005). This holds particularly true for persons with a migrational background. While migrants have a higher average start-up propensity than natives in Germany (Kohn and Spengler, 2007), a large proportion of migrants comes from Islamic countries, where males participate disproportionately in the labor market. The observed start-up rate among migrants might thus be driven by a particularly high rate among male entrepreneurs.

Reconciling family and participation in the labor market is crucial to employment decisions of both men and women. Housework, family childcare, and care for the elderly still are mainly a female domain, and so family environment is likely to play a more important role for women's employment decisions as compared to men's. The effect of family involvement on the decision to start a self-employment is ambiguous though (McManus, 2001). On the one hand, additional family and housework duties generally result in a lower labor force participation rate, reducing the propensity for both dependent and self-employment. On the other hand, self-employment offers a higher degree of flexibility than jobs in dependent employment. The opportunity to work at home and to arrange working hours more freely facilitates reconciling work and family life. ${ }^{12}$ Ceteris paribus, this would increase especially female entrepreneurship.

An analogous reasoning holds for the effect of being head of a household. Primary income earners-very often men-are more likely to be self-employed due to their higher participation rate. On the other hand, support by partners and family members has been shown

\footnotetext{
${ }^{11}$ Compare, e.g., Carr (1996), Leicht et al., (2004), Leicht and Lauxen-Ulbrich (2005), McManus (2001), Tonoyan et al. (2008), Verheul et al. (2004). Strohmeyer and Tonoyan (2008) note that occupational segregation is also responsible for a male-female innovation gap which itself is related to the smaller employment growth in women-owned firms.

${ }^{12}$ See Boden (1996), Brush (1992), Carr (1996), Gurley-Calvezet al. (2009), and Lohmann (2001) for empirical evidence.
} 
to have a positive effect on entrepreneurial propensity as well. The income earned by the primary earner and her/his potential entrepreneurial experience would also increase the startup propensity of the spouse. ${ }^{13}$

As to the effect of children on the start-up propensity of their parents, empirical evidence is mixed. A number of studies for the United States report a positive effect of young children on the entrepreneurial propensity of women, while there is no effect on men. ${ }^{14}$ For Germany, Lohmann (2001) finds a positive effect for mothers with older children, but none for mothers with young children. Constant and Shachmurove (2003) note that West German men have a higher start-up propensity if there are children below the age of 17 in the household.

As lower human capital renders the accumulation of financial capital more difficult, discontinued employment histories and lower income from salaried employment contribute to less financial resources of women, which in turn constrain the start-up decision. ${ }^{15}$ Moreover, social capital and networks are crucial for the recognition of entrepreneurial opportunities, for establishing business contacts, and the exchange of scarce resources. Aldrich et al. (1989) hypothesize that women use different networks than men, but again, empirical evidence is mixed. While Caputo and Dolinsky (1998), Cromie and Birley (1992), and Jungbauer-Gans (1993) find no gender differences in networking activity and network densities, Renzulli et al. (1999) conclude that different network compositions among men and women are important determinants of the start-up decision. Gender differences in social capital and networking activity vary across cultural contexts, or between individuals from different migrational backgrounds.

\subsection{Start-Up Propensity and Individual Personality}

Entrepreneurial personality is crucial for the individual decision to start up a business and the subsequent entrepreneurial activity. Schumpeter (1934), for example, identified entrepreneurs as extraordinary individuals defying conventions, originating innovations, and thus promoting creative destruction. Entrepreneurs recognize and exploit entrepreneurial opportunities (Kirzner, 1973) and they are willing to take risk and uncertainty (Knight, 1921).

According to the theory of planned behavior (Ajzen, 1985, 1991), the interaction of social norms, individual attitudes, and subjective perceptions entail the intentions of a person, which in turn govern individual decisions and actions. ${ }^{16}$ Personal attributes thus determine whether a

\footnotetext{
${ }^{13}$ See, e.g., Bruce (1999), Caputo and Dolinsky (1998), Carr (1996), and Lauxen-Ulbrich et al. (2004).

${ }^{14}$ Boden (1999), Caputto and Dolinsky (1998), Carr (1996).

${ }^{15}$ See Caputo and Dolinsky (1998); Haynes and Haynes (1999), and Verheul and Thurik (2001).

${ }^{16}$ See Krueger (2003) for a synopsis of related models in cognitive psychology.
} 
potential entrepreneur recognizes or creates, and thereupon exploits a business opportunity. ${ }^{17}$ Dimensions of personality identified in differential psychology include, e.g., the 'big five' factors extraversion, emotional stability, agreeableness, conscientiousness, and openness. ${ }^{18}$ In the entrepreneurship context, general personality traits as well as attitudes towards entrepreneurship are relevant for the individual start-up decision.

Shane (2003) surveys various personality traits which have been identified to promote entrepreneurial activity. These include, i.a., imagination and creativity, internal locus of control and self-efficacy, extraversion, and need for achievement. On the other hand, traits such as risk aversion and agreeableness are typical non-entrepreneurial ones. Personality traits differ between men and women. For example, women have been found to be more risk averse but also emotionally more stable, and they have a lower self-efficacy (Wilson et al., 2007; Caliendo et al., 2009). ${ }^{19}$ Some studies compare female and male entrepreneurs with respect to psychological characteristics. ${ }^{20}$ Female entrepreneurs put a higher emphasis on autonomy, self-actualization and adaptability, but they are less profit-driven. Case studies corroborate the notion that female entrepreneurs act more cautiously and more deliberately, but also more anxiously and uncertain than their male counterparts (Tchouvakhina, 2004). Gender differences in general personality traits may thus contribute to explaining the lower start-up rate among women.

Entrepreneurship-related attitudes comprise self-perceptions as well as subjective perceptions of the start-up environment. In this context, 'overconfidence' (Hoffrage, 2004) and unrealistic optimism have been shown to be disproportionately prevalent among entrepreneurs. ${ }^{21}$ Although entrepreneurship does not pay off for a majority of business starters due to high business mortality and a lower average income of self-employed workers as compared to employees (Hamilton, 2000), entrepreneurs systematically assess their own entrepreneurial aptitude and the economic and personal start-up environment more positively than nonentrepreneurs. In turn, these positive assessments have an important impact on the intention to start a business (Gatewood et al., 1995; Krueger et al., 2000).

A few large-scale population surveys provide information on entrepreneurship-related individual attitudes. Using data from the Global Entrepreneurship Monitor (GEM), Arenius

\footnotetext{
${ }^{17}$ Cp. the surveys of Eckhardt and Shane (2003), Sarasvathy et al. (2003), and Shane (2003).

${ }^{18}$ See, e.g., Digman (1990).

${ }^{19}$ Using data from the German Socio-Economic Panel (GSOEP), Caliendo et al. (2009) note that higher risk aversion decreases the propensity to start a business among persons in regular employment (but not among unemployed or persons out of the labor force). The effect turns out similar for men and women.

${ }^{20}$ Cp. Sexton and Bowman-Upton (1990) and the survey of Brush (1992).

${ }^{21}$ Cp. Cramerer and Lovallo (1999), de Meza and Southey (1996), Kohn and Spengler (2008a), and Köllinger et al. (2007).
} 
and Minniti (2005) confirm that subjective perceptions about the suitability of economic conditions for a start-up, as well as perceptions of one's own entrepreneurial aptitude correlate positively with individual start-up propensity. Langowitz and Minniti (2007), using the same data set, focus on gender differences and conclude that women's less positive attitudes about their entrepreneurial aptitude and about the start-up environment contribute to the lower start-up propensity among women. Referring to the German Regional Entrepreneurship Monitor (REM), Wagner (2007) stresses higher fear of failure as a driving factor behind women's lower start-up propensity. ${ }^{22}$ Gender differences in entrepreneurial attitudes also persist after controlling for additional individual characteristics: ceteris paribus, women show a lower level of optimism and start-up-related self-confidence, as well as a higher fear of failure (Köllinger et al., 2008).

In sum, women have different entrepreneurship-related attitudes than men. Insofar as these attitudes are related to the start-up decision, they may contribute to the observed gender difference in start-up rates. Yet a caveat applies when interpreting entrepreneurship-related attitudes collected in survey data. At the time of the survey interview, when intervieweesentrepreneurs and non-entrepreneurs - state their assessments, the decision to start-up or not has already been made. Therefore, the assessments are subject to a hindsight bias (Fischhoff, 1975; Thaler, 2000). Entrepreneurs justify their start-up decision ex post and assign high values to, e.g., their entrepreneurial qualification and economic conditions. Estimated effects of these endogenous attitudes on the individual start-up decision will thus be biased and must not be interpreted as start-up determinants.

\subsection{Relative Importance of Start-Up Determinants}

Socio-demographics as well as personality traits determine individual start-up decisions. The role of each of these determinants for explaining the gender difference in start-up rates might be twofold: First, women and men might differ in characteristics which are relevant to the start-up decision. Second, characteristics might have different impacts on the decisions of women and men.

Some recent studies empirically analyze the relative importance of socio-demographic characteristics and entrepreneurship-related attitudes. Langowitz and Minniti (2007) estimate gender-specific probit models of the start-up decision. Once measures of entrepreneurshiprelated perceptions are included in their estimations, the influence of socio-demographic

\footnotetext{
${ }^{22}$ See also Bergmann (2004) for similar results based on the same data set. Yet Werner and Kay (2006), using a survey data set of individuals visiting start-up fairs in Germany, conclude that entrepreneurial self-perception has no specific gender effect.
} 
variables becomes insignificant for men as well as for women. The authors thus suppose a particular importance of attitudinal differences.

Again using GEM data and employing a non-parametric resampling method, Minniti and Nardone (2007) conclude that gender differences in human capital endowment and household income are negligible in comparison to differences in entrepreneurship-related perceptions. The employed resampling method allows Minniti and Nardone to put men and women in identical economic environments and socio-demographic circumstances without distributional assumptions. However, the pure resampling does not capture behavioral differences for given characteristics.

Wagner (2007) chooses a matching approach and compares the observed start-up rate of men with the estimated rate among matched men with the characteristics of women. The latter turns out larger. So the gender difference in start-up rates would even be higher if men had the same characteristics as women. The observed gender gap would entirely be driven by behavioral differences. However, Wagner's result is fragile insofar as the matching approach relies on few covariates only, and merely the effect of 'fear of failure' differs significantly between men and women.

All in all, the sparse empirical evidence so far suggests that differences in observed characteristics and attitudes, as well as behavioral differences determine the different start-up activity of men and women. Moreover, a strong effect of attitudes or perceptions is expected. Yet all of the above studies make use of entrepreneurship-related attitudes surveyed ex postand therefore suffer from the problem of hindsight bias. Valid empirical models should rely on more general personality traits.

\section{Empirical Investigation}

Our empirical analysis follows a three-step procedure. First, we compare male and female entrepreneurs and non-entrepreneurs with respect to various socio-demographic characteristics and personality traits. This yields insights as to whether men and women have different observable endowments. Second, we estimate probit models of the start-up decision. Testing for equality of effects estimated for men and women then provides insights as to whether the endowments have gender-specific impacts. Third, we predict start-up rates based on our estimates and decompose the gender difference into 'characteristics effects' capturing differences in observed endowments, a 'base effect', and 'coefficients effects', which capture differences in start-up behavior for given characteristics. The decompositions yield insights into the relative importance of the different determinants. 


\subsection{KfW Start-Up Monitor}

We use data from the 2007 KfW Start-up Monitor (cf. Tchouvakhina and Hofmann, 2003/04; Kohn and Spengler, 2008b). The KfW Start-up Monitor is a representative computer-assisted telephone (CATI) survey on start-up activity in Germany. Its yearly cross sections are conducted among 40,000 randomly selected inhabitants. Entrepreneurs are identified as those persons who started a new business or took over an established firm within 12 months before the interview. The employed broad entrepreneurship concept includes industrial and commercial self-employment as well as freelancers, and full-timers as well as part-timers. Entrepreneurs are asked a broad set of questions about their person and their start-up project. In addition, a subsample of 7,500 non-entrepreneurs also answers detailed questions about their socio-demographic background, and thus serves as a comparison group. Table B.1 in Appendix B displays the definitions of corresponding variables used in our analysis.

In addition to conventional socio-demographics, the 2007 questionnaire contains a broad range of personality-related questions, comprising both general personality traits and entrepreneurship-related attitudes (Table B.2 in Appendix B). On the one hand, interviewees revealed their subjective perceptions about the suitability of current economic conditions and their personal life circumstances for a business start-up, the desirability of self-employment, the reputation of entrepreneurs, and their individual entrepreneurial aptitude on a five-point Likert scale. On the other hand, they assessed more general statements regarding personality traits such as risk tolerance, openness, cognitive skills, need for achievement, emotional stability, persuasiveness, creativity, and determination. ${ }^{23}$ Statements and associated variables are displayed in Table B.2 in Appendix B.

\subsection{Gender-Specific Start-Up Intensities}

Women participate less in entrepreneurial activity than men. In the year 2007, gender-specific start-up intensities-i.e., the share of female or male business starters in the respective population aged 18-64 years-were 2.1\% among males and 1.3\% among females. The evolution of women's share in all entrepreneurs over the years $2000-2007$ is displayed in Figure 1.

- Figure 1 about here -

With a variation between 34 and $40 \%$, women's share is always considerably below $50 \%$. Moreover, their share among full-time entrepreneurs (28 to 37\%) is markedly lower than their

\footnotetext{
${ }^{23}$ Note that the design of a large population survey does not permit the use of different items for single dimensions of personality.
} 
share among part-timers (36 to 46\%). So starting a business as a part-time project is a relatively attractive option for women who wish to combine employment and housework duties or parenting. In addition, women might be more cautious and therefore choose the lower risk of a part-time start-up first, with the option of switching to full-time selfemployment after a successful establishment of their business (Tchouvakhina and Tilleßen, 2006).

Over time, women's share in part-time entrepreneurs varied merely unsystematically. Yet the respective share among all full-time entrepreneurs has been steadily increasing since the year 2003. The increasing inflow results in a growing stock of self-employed women (LauxenUlbrich and Leicht, 2005). On the one hand, this evolution is in line with recent years' trend towards growing labor force participation of women. On the other hand, women may also have seized their start-up chances during the economic upswing to a larger extent than men.

\subsection{Characteristics of Entrepreneurs and Non-Entrepreneurs by Gender}

Table 1 compares socio-demographic characteristics, personality traits, and entrepreneurshiprelated attitudes of men and women, distinguished by their entrepreneurial status.

- Table 1 about here -

On average, female entrepreneurs start at a significantly higher age as compared to their male counterparts. They first start a family and decide for a start-up later. As to educational attainment, males went to a technical school more often and hold a degree as a master craftsman or technician. Apart from this, female and male entrepreneurs are educated equally well. Women more often start from out of the labor force or from white-collar occupations, and less often from blue-collar occupations. On the other hand, male starters have more often gained experience in previous self-employment or in leading positions as executive employees.

The share of entrepreneurs from Eastern Germany and the share of foreigners both are lower among women than among men. Male entrepreneurs more often live alone in their household, but on average, female entrepreneurs are more often responsible for running the household. Moreover, young children are comparably common in households with female entrepreneurs. When comparing males and females in the population of non-entrepreneurs, one partly observes the same gender differences as among entrepreneurs. For example, the male dominance among technicians and master craftsmen, the prevalence in different professional statuses, and distribution of household and family work also shows among non-entrepreneurs. However, there are only minor gender differences in the distributions of age, migrational 
status, and region of residence. As a consequence, young men and men with a migrational background are overrepresented in start-up activity, while women from Eastern Germany and men from small cities are underrepresented.

Regarding general personality traits, male entrepreneurs have a significantly higher need for achievement and assess themselves a higher level of cognitive skills as compared to female entrepreneurs. Yet the same gender differences hold true among non-entrepreneurs. ${ }^{24}$ The overall level of approval varies markedly between the different traits. For example, risk tolerance and openness receive low scores of approval, while need for achievement and determination receive high ones. What is more, entrepreneurs of both genders generally report higher scores concerning all personality traits (except for emotional stability) as compared to non-entrepreneurs. They are less risk averse, more open and more persuasive, more creative and more determined, and they have a higher need for achievement.

As the personality scores stem from self-assessments of the survey participants, we cannot be sure whether the observed differences reflect true differences in traits or also result from a more affirmative assessment behavior of starters. However, as the chosen statements are not directly related to business start-ups, observed differences are valid for explaining the start-up decision and respective gender differences.

Asked for entrepreneurship-related attitudes, male starters consider the suitability of economic conditions for their start-up, as well as the reputation of entrepreneurs in general, significantly more positive than female starters. Further gender differences-regarding the general desirability of self-employment, the suitability of personal circumstances for a business start-up, and personal entrepreneurial aptitude-turn out insignificant among the group of starters. In the population of non-starters, however, men assign higher scores to almost all attitudes than women. In addition, starters of both genders generally report higher scores than non-starters. Entrepreneurs' reputation is the only exception. While entrepreneurs have quite a positive reputation in the entire population, entrepreneurs themselves become disillusioned after a start-up-and this holds particularly for women entrepreneurs.

These results indicate the presence of entrepreneurial overconfidence among female as well as male business starters. Moreover, as the entrepreneurship-related attitudes are clearly endogenous to the start-up decision, they should not be used as determinants when estimating the individual start-up decision.

\footnotetext{
${ }^{24}$ Note that gender differences turn out significant among non-starters more easily as the number of non-starters in the sample is much higher than the number of starters.
} 


\subsection{Regression of Start-Up Decision}

We estimate probit models of the individual start-up decision. ${ }^{25}$ Table 2 displays the results of pooled regressions for men and women.

- Table 2 about here -

Specification (1) of Table 2 uses all observations in the sample. On average, the start-up propensity of women is significantly lower than men's by 0.9 percentage points (pp). Compared to the (unweighted) reference probability of $2.6 \%$ among males, this amounts to a difference of about one third. ${ }^{26}$ A similar gender difference is obtained from specification (2), which uses only observations from the estimation subsample, in which business starters are explicitly overrepresented. ${ }^{27}$ Moreover, the negative gender effect basically prevails when controlling for socio-demographics (specification 3) and personality traits (specification 4).

The effects of socio-demographic variables estimated in specification (3) broadly confirm expectations from the descriptive comparison of entrepreneurs and non-entrepreneurs above. For example, we observe an inverted U-shape influence of age on individual start-up propensity. A higher educational attainment increases the probability of a start-up, as well as previous self-employment or unemployment spells, or non-participation in the labor market. Working in blue-collar occupations as well as being a civil servant decreases the start-up probability (relative to white-collar occupations). While ceteris paribus individuals from Eastern Germany have a lower start-up propensity, there are no significant differences between persons with a migrational background and those without. When controlling, i.a., for professional status and age, there are no significant differences related to household and family compositions.

Specification (4) of Table 2 additionally includes personality traits. Ceteris paribus, openness to change, need for achievement, persuasiveness, and creativity increase the probability of a start-up, while the other traits have no significant effect. In comparison to specification (3), the impact of most socio-demographic variables remains unchanged. Including personality traits thus provides additional information to explain the start-up decision. ${ }^{28}$ Only the effect of previous self-employment loses significance and gets negligibly small. Thus self-employed

\footnotetext{
${ }^{25}$ As an alternative to estimating probit models, we also estimated linear probability models (LPM). LPM results, which are generally in line with the probit ones, are available from the authors upon request. Appendix A.1 introduces our estimation notation in order to facilitate the exposition of the decomposition approach employed below.

$26-0.0090 / 0.0263=-0.3422$.

${ }^{27}$ The estimation subsample contains all business-starters as well as the first 7,500 non-starters in the sample, for whom socio-demographic characteristics and personality variables are available. The oversampling of starters is one way to circumvent the rare-events problem frequently encountered when estimating the start-up decision. The estimated relative gender difference is $-0.0342 / 0.1104=-0.3098$.

${ }^{28}$ The Pseudo $\mathrm{R}^{2}$ also increases markedly from specification (3) to specification (4).
} 
persons - whether they have recently started an (additional) project or not—stand out as individuals with a disproportionately entrepreneurial personality. It is this personality rather than the status of self-employment per se which drives the start-up decision.

Separate, gender-specific probits are estimated in Table 3. This allows the impacts of the covariates to vary between males and females. ${ }^{29}$

\section{- Table 3 about here -}

By and large, the determinants are similar to those obtained from the pooled regressions above. However, there are some notable gender differences in the partial effects. For instance, we find countervailing effects of age. While younger men start-up significantly more often than men aged 35 to 44 years, older women are less likely to start than medium-aged women. This ceteris paribus effect is in contrast to the observed unconditional picture. Hence older women might face higher opportunity costs of a start-up stemming, e.g., from a stronger involvement in family duties. Alternatively, their discontinued employment histories might hamper later years' re-entry in the labor market in general, and start-ups into self-employment in particular.

Women with a university or technical college degree, as well as women from out of the labor force have a higher propensity to start a business (as compared to the respective reference categories). The corresponding effects among males tend to be smaller. The observed difference in start-up rates between Eastern and Western Germany is driven by females only. Whereas women in East Germany start significantly less often than women in the West, there is no East-West difference among males. This result likely reflects the higher participation rate in dependent employment among East German women. ${ }^{30}$

Relative to Germans, men with a migrational background have a significantly higher propensity of a business start-up. Yet there is no migrational effect among women. This observation likely results from traditional role models among migrants from Turkey and Eastern Europe, who account for the lion's share of persons with a migrational background (Kohn and Spengler, 2007). Finally, while again duties of running the household have no ceteris paribus effects on the start-up decision, the presence of children in the household significantly increases the start-up probability of men, but it does not affect women's start-up decisions.

\footnotetext{
${ }^{29}$ Tests for significance of the differences displayed in columns (5) and (6) of Table 3 are obtained from fully interacted pooled estimations.

${ }^{30}$ In the year 2005, labor force participation rates among females were $72.1 \%$ (65.5\%) in Eastern (Western) Germany. With respective numbers of $79.1 \%$ (East) and $80.8 \%$ (West) there were basically no differences among males (Bundesagentur für Arbeit, 2007).
} 
Columns (3) and (4) of Table 3 additionally account for personality traits. As it turns out, a higher degree of risk tolerance has a positive impact on men's start-up decisions, but it does not influence women's decisions. In this respect-given the similar distributions of risk aversion among men and women-men are more likely to start up. On the other hand, persuasiveness increases the start-up probability of women only. It has no effect among men. After all, need for achievement is an important determinant among both men and women. Yet the effect of this trait is significantly larger for males.

In sum, the regression results first corroborate the notion that the start-up decisions of men and women are-to some extent—driven by different determinants. Second, the pure gender effect, which is not explained by any observable characteristic, is markedly reduced when personality traits are included in the regressions. ${ }^{31}$ The latter might thus explain a sizeable proportion of the observed gender difference in start-up rates.

\subsection{Prediction and Decompositions}

Based on the separate probit estimations and using the notation sketched in Appendix A.1, we calculate average predicted probabilities of a business start-up for both genders $g \in\{\mathrm{m}, \mathrm{f}\}$ :

$$
\hat{Y}^{g}=N_{g}^{-1} \sum_{i=1}^{N_{g}} \Phi\left(X_{i}^{g} \hat{\beta}^{g}\right)=N_{g}^{-1} \sum_{i=1}^{N_{g}} \Phi\left(\hat{\beta}_{0}^{g}+Z_{i}^{g} \hat{\beta}_{Z}^{g}+W_{i}^{g} \hat{\beta}_{W}^{g}\right) .
$$

The projections displayed in the first block of Table 4 below consistently trace the observed shares. Whether personality traits are included in the analysis or not, the average projection for women is lower by one third as compared to the average projection for men. ${ }^{32}$

\section{Differences in Observed Characteristics and Behavioral Effects}

How much of the gender difference in start-up rates is due to differences in observable sociodemographic characteristics? How much is explained by different personality traits? And how large is the contribution of behavioral effects for given socio-demographics and personality traits? As a first step to answer these questions, we use standard Blinder-Oaxaca-type

\footnotetext{
${ }^{31}$ Referring to the estimated reference probabilities, a relative gender difference of $(0.0777-0.0564) / 0.0777=$ 0.2741 results from specifications (1) and (2). Specifications (3) and (4) result in $(0.0610-0.0664) / 0.610=-$ 0.0885 .

${ }^{32} 0.0361 / 0.1083=0.3333$, just as $0.0362 / 0.1085=0.3336$. Compare the figures in footnote 26 .
} 
decompositions adapted to the non-linear case. ${ }^{33}$ The difference in projected start-up rates is decomposed into a 'characteristics effect' and a 'coefficients effect':

$$
\hat{Y}^{m}-\hat{Y}^{f}=\underbrace{\hat{Y}^{m}-\hat{Y}_{m}^{f}}_{\text {characteristics effect }}+\underbrace{\hat{Y}_{m}^{f}-\hat{Y}^{f}}_{\text {coefficients effect }}=\underbrace{\hat{Y}_{f}^{m}-\hat{Y}^{f}}_{\text {characteristics effect }}+\underbrace{\hat{Y}^{m}-\hat{Y}_{f}^{m}}_{\text {coefficients effect }}
$$

where $\hat{Y}^{g}$ are defined in equation (1). The characteristics (or endowment) effect captures a first part of the gap which is attributed to gender differences in the distribution of observed characteristics (both socio-demographics and personality traits). The coefficients (or returns) effect captures a second part of the gap which is due to differences in the coefficients estimated for both genders. Economically speaking, the coefficients effect reflects gender difference in behavior for given characteristics.

The decompositions in equation (2) differ with respect to the underlying counterfactual situations $\hat{Y}_{g}^{\tilde{g}}$. The first counterfactual, $\hat{Y}_{m}^{f}$, denotes the predicted start-up rate of a hypothetical person with the average characteristics of females, given the person was facing the returns of males. In contrast, the second counterfactual, $\hat{Y}_{f}^{m}$, uses the estimated returns of women and denotes the projected start-up rate of a hypothetical person with the average characteristics of males. ${ }^{34}$ The construction of the counterfactuals is described in Appendix A.2. Table 4 reports results of the respective decompositions.

\section{- Table 4 about here -}

Differences in socio-demographic characteristics alone explain only a negligible proportion of the gender gap in start-up rates. In column (A) of Table 4, the characteristics effect does not exceed a share of $11 \%$. Adding differences in personality traits in column (B) increases the characteristics effect to the range of 11 to $22 \%$. Hence, if women had the same sociodemographics and the same personality traits as men, the gender gap would be reduced by up to one fifth. Taken at face value, this thought experiment would increase women's start-up intensity from 1.3 to $1.4 \%$ or $1.5 \% .^{35}$ In turn, the larger proportion of the gender gap (78 to 89\%) can not be explained by differences in observed characteristics at all, but is driven by behavioral differences for given characteristics and differences in unobserved determinants.

\footnotetext{
${ }^{33}$ Blinder (1973), Oaxaca (1973). Compare also Fairlie (1999, 2005) and Fairlie and Robb (2007).

${ }^{34}$ It is well-known that the decompositions resulting from different counterfactuals do not necessarily yield identical results. Different approaches to the issue of non-uniqueness have been proposed in the literature; see Oaxaca and Ransom (1994) and Silber and Weber (1999) for surveys. Yet each of the approaches relies on adhoc assumptions of some type, so we choose to report the two most prominent cases.

${ }^{35}(2.1 \%-1.3 \%) \cdot 0.108=+0.1 \%$ and $(2.1 \%-1.3 \%) \cdot 0.219=+0.2 \%$.
} 


\section{Relative Importance of Socio-Demographics, Personality, and a Base Effect}

A more detailed decomposition provides insights into the relative importance of sociodemographics $Z_{i}$ personality traits $W_{i}$, and a base effect:

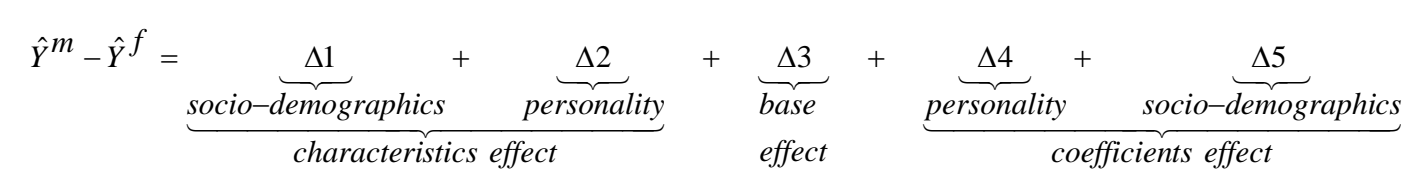

As again there are multiple counterfactuals possible, our choice is motivated by economic reasoning. Starting out from women, we first ask what their start-up rate would look like if they only had the same socio-demographic characteristics as men. Our first hypothetical person would thus exhibit the socio-demographics of males and personality traits of females, and behave like a woman. Abusing, for simplification, the notation of equation (2), the corresponding change in predicted start-up rates writes

$$
\Delta 1=Y\left(Z^{m}, W^{f}, \hat{\beta}_{0}^{f}, \hat{\beta}_{Z}^{f}, \hat{\beta}_{W}^{f}\right)-Y\left(Z^{f}, W^{f}, \hat{\beta}_{0}^{f}, \hat{\beta}_{Z}^{f}, \hat{\beta}_{W}^{f}\right)
$$

Details of the extended decomposition, including the construction of the additional counterfactuals using Mahalanobis distance matching, are given in Appendix A.3. Table 5 displays the calculation results. With a relative contribution of $-19 \%$, differences in sociodemographics alone are in favor of higher start-up rates among women. Put differently, if women had the same human capital endowment and related socio-demographic background as men, their start-up propensity would have been even lower by $19 \%$.

If in addition, women also had the same 'soft' personality traits as men but still behaved like women for given characteristics, their start-up rate would additionally change by

$$
\Delta 2=Y\left(Z^{m}, W^{m}, \hat{\beta}_{0}^{f}, \hat{\beta}_{Z}^{f}, \hat{\beta}_{W}^{f}\right)-Y\left(Z^{m}, W^{f}, \hat{\beta}_{0}^{f}, \hat{\beta}_{Z}^{f}, \hat{\beta}_{W}^{f}\right) .
$$

As it turns out, these personality differences captured by traits such as need for achievement, risk aversion, or determination contributes a considerable and significant proportion of 30\% of the entire gender difference.

How much of the gender difference is explained by unobserved characteristics, then? This base effect is obtained from $\Delta 3$, where the additional counterfactual would, for given characteristics, still behave like a woman but exhibit both observable characteristics and unobservable characteristics of men. Technically speaking, the base effect captures differences in the estimation constants:

$$
\Delta 3=Y\left(Z^{m}, W^{m}, \hat{\beta}_{0}^{m}, \hat{\beta}_{Z}^{f}, \hat{\beta}_{W}^{f}\right)-Y\left(Z^{m}, W^{m}, \hat{\beta}_{0}^{f}, \hat{\beta}_{Z}^{f}, \hat{\beta}_{W}^{f}\right) .
$$


Just as the differences in observable socio-demographics, unobserved effects work towards reducing the gender gap. The estimated contribution of $-54 \%$ is not statistically significant, though.

Start-up rates would gain change incrementally if the impact of personality traits equaled the effect exerted on men. The involved final counterfactual in $\Delta 4$ would thus be a person with (observed and unobserved) characteristics of men, who hypothetically behaved like a man regarding the effect of personality traits, but still behaved like a women for given sociodemographics:

$$
\Delta 4=Y\left(Z^{m}, W^{m}, \hat{\beta}_{0}^{m}, \hat{\beta}_{Z}^{f}, \hat{\beta}_{W}^{m}\right)-Y\left(Z^{m}, W^{m}, \hat{\beta}_{0}^{m}, \hat{\beta}_{Z}^{f}, \hat{\beta}_{W}^{f}\right) .
$$

With a relative contribution of $28 \%$, this difference in the effects of the included personality traits is of the same size as the corresponding characteristics effect $\Delta 2$ and also explains about a quarter of the predicted gender gap.

Increment $\Delta 5$ finally asks about the impact on the predicted start-up rate if also the sociodemographics exerted the same effects as on men:

$$
\Delta 5=Y\left(Z^{m}, W^{m}, \hat{\beta}_{0}^{m}, \hat{\beta}_{Z}^{m}, \hat{\beta}_{W}^{m}\right)-Y\left(Z^{m}, W^{m}, \hat{\beta}_{0}^{m}, \hat{\beta}_{Z}^{f}, \hat{\beta}_{W}^{m}\right) .
$$

This part of the difference turns out responsible for the largest proportion of the gender gap. Moreover, the estimated contribution (115\%) is even larger than the predicted gender gap itself, indicating that the gap would be even higher if men and women only differed in their start-up behavior for given socio-demographic characteristics.

- Table 5 about here -

In a nutshell, gender differences in socio-demographics alone would be in favor of higher start-up rates among women, while the distribution of personality traits is less favorable for business start-ups among women and explains about one third of the entire gender difference. Differences in unobserved characteristics again work in the direction of a lower gender difference. Yet both behavioral effects are in favor of the observed higher start-up rate among men. Most substantially, men opt for a start-up more often even given identical endowments with human capital and related characteristics.

\section{Concluding Remarks}

As a stylized fact observed in many industrial countries, women start fewer businesses than men. The gender gap in start-up rates shows in descriptive comparisons, but also remains after controlling for a number of impact factors which are relevant to the individual start-up 
decision. Our analysis based on unique large-scale individual-level data from the KfW Startup Monitor for Germany reveals that the gender gap is related to differences in 'hard' sociodemographic characteristics_-such as age, educational attainment and professional status, region of residence and migrational background, or household and family environment—as well as to different distributions of 'soft' personality traits— such as risk aversion, openness to change, persuasiveness, and need for achievement.

More importantly, our approach assesses the relative importance of different blocks of startup determinants for explaining the gender gap in start-up intensity. The lion's share of the observed gap is due to behavioral differences and unobserved dissimilarities beyond differences in observable endowments. This finding is broadly in line with those obtained by Minniti and Nardone (2007) and Wagner (2007) who conclude that differences in human capital are largely negligible for explaining the gender gap. Taking a more subtle view when comparing the relative importance of gender differences in socio-demographics and in personality traits, we find that women's personality traits are less favorable to a start-up than men's, but their human capital endowment alone would even be in favor of a higher start-up rate among women.

The finding that women's personality makes them less inclined to start-up a business may be judged positively insofar as entrepreneurial overconfidence (Cramerer and Lovallo, 1999, Köllinger et al., 2007) or unrealistic optimism (de Meza and Southey, 1996) are less prevalent among females, who therefore act more cautiously_and possibly more successfully in the long run. On the other hand, the finding is individually and socially detrimental if women's personality prevents them from undertaking promising projects.

Given the results of our study, qualificational policies targeted towards higher educational attainments of potential entrepreneurs alone do not suffice to increase the number of female business starters and to close the gender gap. Supporting women with respect to personality traits and perceptions relevant to the start-up decision would be at least as important. This is clearly a challenging task. Whether measures such as, for instance, consulting activities or networks of successful female entrepreneurs can achieve this goal remains to be seen. 


\section{References}

Ajzen, I. (1985): From Intentions to Actions: A Theory of Planned Behavior, in: J. Kuhl and J. Beckmann (eds.), Action-Control: from Cognition to Behavior, Springer, Heidelberg, pp. 11-39.

Ajzen, I. (1991): The Theory of Planned Behavior, Organizational Behavior and Human Decision Processes 50, 179-211.

Aldrich, H., R. P. Reese, and P. Dubini (1989): Women on the verge of a breakthrough: networking among entrepreneurs in the United States and Italy, Entrepreneurship and Regional Development 1(4), 339-356.

Allen, I. E., N. Langowitz, and M. Minniti (2007): Global Entrepreneurship Monitor - 2006 Report on Women and Entrepreneurship, Babson College and London Business School.

Arenius, P., and M. Minniti (2005): Perceptual Variables and Nascent Entrepreneurship, Small Business Economics 24, 233-247.

Becker, G. S. (1964): Human Capital. A Theoretical and Empirical Analysis, with Special Reference to Education, 3. ed., University of Chicago Press, Chicago, 1993.

Bergmann, H. (2004): Determinanten von Gründungsaktivitäten, Zeitschrift für KMU und Entrepreneurship 52(4), 235-252.

Blanchflower, D. G., and A. J. Oswald (1998): What Makes an Entrepreneur?, Journal of Labor Economics 16(1), 26-60.

Blinder, A. S. (1973): Wage Discrimination: Reduced Form and Structural Estimates, Journal of Human Resources 8(4), 436-455.

BMWAÖ (2008): Selbständigenquote im EU-Vergleich, Bundesministerium für Wirtschaft und Arbeit des Landes Österreich, http://elis.bmwa.gv.at/Arbeitsmarkt/xls/aminter_SELBSTQinter.xls, accessed Aug. 12, 2008.

Boden Jr., R. J. (1996): Gender and Self-Employment Selection: An Empirical Assessment, Journal of Socio-Economics 25(6), 671-682.

Boden Jr., R. J. (1999): Flexible Working Hours, Family Responsibilities, and the Female Self-Employment, American Journal of Economics and Sociology 58(1), 71-83.

Boden, R. J., and A. R. Nucci (2000): On the survival prospects of men's and women's new business ventures, Journal of Business Venturing 15(4), 347-362.

Bönte, W., O. Falck, and S. Heblich (2007): Demography and Innovative Entrepreneurship, CESifo Working Paper 2115, München. 
Bruce, D. (1999): Do Husbands Matter? Married Women Entering Self Employment, Small Business Economics 13(4), 317-329.

Brush, C. G. (1992): Research on Women Business Owners: Past Trends, a New Perspective and Future Directions, Entrepreneurship Theory and Practice 6(4), 5-30.

Brush, C. G. (2006): Women Entrepreneurs: A Research Overview, in: M. Casson, B. Yeung, A. Basu, and N. Wadeson (eds.), The Oxford Handbook of Entrepreneurship, Oxford University Press, Oxford, pp. 611-628.

Bundesagentur für Arbeit (2007): Arbeitsmarkt 2006. Amtliche Nachrichten der Bundesagentur für Arbeit, 55. Jahrgang, Sondernummer 1, Nürnberg.

Caliendo, M., F. M. Fossen, and A. S. Kritikos (2009): Risk attitudes of nascent entrepreneurs-new evidence from an experimentally validated survey, Small Business Eocnomics 32, 153-167.

Caputo, R. K., and A. Dolinsky (1998): Women's Choice to Pursue Self-Employment: The Role of Financial and Human Capital of Household Members, Journal of Small Business Management 36(3), 8-17.

Carr, D. (1996): Two Paths to Self-Employment? Work and Occupations 23(1), 26-53.

Carter, S., and E. Shaw (2006): Women’s Business Ownership: Recent Research and Policy Development, Small Business Service Research Report, November, London.

Carter, S., S. Anderson, and E. Shaw (2001): Womens's Business Ownership: A Review of the Academic, Popular and Internet Literature, Small Business Service Research Report RR002/01, London.

Constant, A., and Y. Shachmurove (2003): Entrepreneurial Ventures and Wage Differentials between German and Immigrants, IZA Discussion Paper 879, September.

Cooper, A. C. (1981): Strategic Management: New Ventures and Small Business, Long Range Planning 14(5), 39-45.

Cooper, A., F. J. Gimeno-Gascon, and C. Y. Wo (1994): Initial Human and Financial Capitals as Predictors of New Venture Performance, Journal of Business Venturing 9(5), 371396.

Cowling, M., and M. Taylor (2001): Entrepreneurial Women and Men: Two Different Species? Small Business Economics 16(3), 167-175.

Cramerer, C. F., and D. Lovallo (1999): Overconfidence and Excess Entry: An Experimental Approach, American Economic Review 89, 306-318.

Cromie, S., and S. Birley (1992): Networking by female business owners in Northern Ireland, Journal of Business Venturing 7(3), 237-251. 
De Bruin, A., C. G. Brush, and F. Welter (2006): Introduction to the Special Issue: Towards Building Cumulative Knowledge on Women's Entrepreneurship, Entrepreneurship Theory and Practice 30(5), 585-593.

De Bruin, A., C. G. Brush, and F. Welter (2007): Advancing a Framework for Coherent Research on Women's Entrepreneurship, Entrepreneurship Theory and Practice 31(4), 323-339.

De Meza, D., and C. Southey (1996): The Borrower's Curse: Optimism, Finance and Entrepreneurship, Economic Journal 106, 375-386.

DeTienne, D. R., and G. N. Chandler (2007): The role of gender in opportunity identification, Entrepreneurship Theory and Practice 31(3), 365-386.

Digman, J. M. (1990): Personality Structure: Emergence of the Five-Factor Model, Annual Review of Psychology 41, 417-440.

Dolinsky, A., R. Caputo, K. Pasumarty, and H. Quazi (1993): The effects of education on business ownership: A longitudinal study of women, Entrepreneurship Theory and Practice 18(1), 43-53.

Eckhardt, J. T., and S. A. Shane (2003): Opportunities and Entrepreneurship, Journal of Management 29, 333-349.

Evans, D. S., and L. S. Leighton (1989): Some Empirical Aspects of Entrepreneurship, American Economic Review 79(3), 519-535.

Fairlie, R. W. (1999): The Absence of the African-American Owned Business: An Analysis of the Dynamics of Self-Employment, Journal of Labor Economics 17(1), 80-108.

Fairlie, R. W. (2005): An extension of the Blinder-Oaxaca decomposition technique to logit and probit models, Journal of Economic and Social Measurement 30, 305-316.

Fairlie, R. W., and A. M. Robb (2007): Why Are Black-Owned Businesses Less Successful than White-Owned Businesses? The Role of Families, Inheritances, and Business Human Capital, Journal of Labor Economics 25(2), 289-323.

Fischer, E. M., A. R. Reuber, and L. S. Dyke (1993): A theoretical overview and extension of research on sex, gender and entrepreneurship, Journal of Business Venturing 8(2), 151-168.

Fischhoff, B. (1975): Hindsight Is Not Equal to Foresight: The Effect of Outcome Knowledge on Judgement under Uncertainty, Journal of Experimental Psychology: Human Perception and Performance 1, 288-299.

Gatewood, E. J., K. G. Shaver, and W. B. Gartner (1995): A Longitudinal Study of Cognitive Factors Influencing Start-Up Behaviors and Success at Venture Creation, Journal of Business Venturing 10, 371-391.

Gottschalk, S., and S. Theuer (2008): Die Auswirkungen des demografischen Wandels auf das Gründungsgeschehen in Deutschland, Discussion Paper 08-032, ZEW Mannheim. 
Greene, P. G., M. M. Hart, E. J. Gatewood, C. G. Brush, and N. C. Carter (2003): Women Entrepreneurs: Moving Front and Center: An Overview of Research and Theory, USASBE White Papers, United States Association for Small Business and Entrepreneurship.

Gurley-Calvez, T., A. Biehl,K. Harper (2009): Human Capital and Women Entrepreneurs, American Economic Review 99(2), 139-144.

Harrison, R. T., and C. M. Mason (2007): Does gender matter? Women business angels and the supply of entrepreneurial finance, Entrepreneurship Theory and Practice 31(3), 445-472.

Haynes, G. W., and D. C. Haynes (1999): The Debt Structure of Small Business Owned by Women in 1987 and 1993, Journal of Small Business Management 37(2), 1-19.

Hoffrage, U. (2004): Overconfidence, in: R. F. Pohl (ed.), cognitive illusions - a handbook on fallacies and biases in thinking, judgement and memory, Psychology Press, Hove, pp. 235-254.

Jungbauer-Gans, M. (1993): Frauen als Unternehmerinnen - Eine Untersuchung der Erfolgsund Überlebenschancen neugegründeter Frauen- und Männerbetriebe, Lang, Frankfurt am Main.

KfW Bankengruppe (eds.) (2004): Chefinnensache - Frauen in der unternehmerischen Praxis, Physica, Heidelberg.

Kirzner, I. M. (1973): Competition and Entrepreneurship, Chicago University Press, Chicago.

Knight, F. H. (1921): Risk, Uncertainty and Profit, Houghton-Mifflin, New York.

Kohn, K., and H. Spengler (2007): Unternehmensgründungen von Personen mit Migrationshintergrund, FINANZ BETRIEB 9(11), 706-710.

Kohn, K., and H. Spengler (2008a): Subjective Perceptions and the Survival of Business Start-Ups - An Instrumental Variables Approach, mimeo May 2008, KfW Bankengruppe, Frankfurt am Main.

Kohn, K., and H. Spengler (2008b): KfW-Gründungsmonitor 2008. Gründungen in Deutschland: weniger aber besser - Chancenmotiv rückt in den Vordergrund, KfW Bankengruppe, Frankfurt am Main.

Kohn, K., and H. Spengler (2008c): Gründungsintensität, Gründungsqualität und alternde Bevölkerung, Zeitschrift für KMU und Entrepreneurship 56, 253-271.

Köllinger, P., M. Minniti, and C. Schade (2007): “I think I can, I think I can”: Overconfidence and entrepreneurial behavior, Journal of Economic Psychology 28, 502-527.

Köllinger, P., M. Minniti, and C. Schade (2008): Seeing the World With Different Eyes: Gender Differences in Perceptions and the Propensity to Start a Business, Discussion Paper 2008-035/3, Tinbergen Institute. 
Krueger Jr., N. F. (2003): The Cognitive Psychology of Entrepreneurship, in: Z. J. Acs and D. B. Audretsch (eds.), Handbook of Entrepreneurship Research, pp. 105-140, Kluwer, New York.

Krueger, N. F., M. D. Reilly, and A. L. Carsrud (2000): Competing Models of Entrepreneurial Intentions, Journal of Business Venturing 15(5), 411-432.

Langowitz, N., and M. Minniti (2007): The Entrepreneurial Propensity of Women, Entrepreneurship Theory and Practice 31(3), 341-364.

Lauxen-Ulbrich, M., and R. Leicht (2005): Wie Frauen gründen und was sie unternehmen: Nationaler Report Deutschland. Teilprojekt: Statistiken über Gründerinnen und selbständige Frauen, Institut für Mittelstandsforschung, Universität Mannheim.

Lauxen-Ulbrich, M., R. Leicht, and S. Fehrenbach (2004): Flexibel zwischen Familie und Beruf? Zur Lebens- und Arbeitsgestaltung selbständiger Frauen, in: R. Leicht and F. Welter (eds.), Gründerinnen und selbständige Frauen. Potentiale, Strukturen und Entwicklungen in Deutschland, von Loeper, Karlsruhe, pp. 138-169.

Leicht, R., and F. Welter (eds.) (2004): Gründerinnen und selbständige Frauen - Potenziale, Strukturen und Entwicklungen in Deutschland, von Loeper, Karlsruhe.

Leicht, R., and M. Lauxen-Ulbrich (2005): Entwicklung und Determinanten von Frauenselbständigkeit in Deutschland - Zum Einfluss von Beruf und Familie, Zeitschrift für KMU und Entrepreneurship 53(2), 133-149.

Leicht, R., M. Lauxen-Ulbrich, and R. Strohmeyer (2004): Selbständige Frauen in Deutschland: Umfang, Entwicklung und Profil, in: KfW Bankengruppe (eds.), Chefinnensache - Frauen in der unternehmerischen Praxis, Physica, Heidelberg, pp. 1-32.

Lévesque, M., and M. Minniti (2006), The Effect of Aging on Entrepreneurial Behavior, Journal of Business Venturing 21, 177-194.

Lohmann, H. (2001): Self-employed or employee, full-time or part-time? Gender differences in the determinants and conditions for self-employment in Europe and the US, Arbeitspapier 38, Mannheimer Zentrum für Europäische Sozialforschung.

McManus, P. A. (2001): Women’s Participation in Self-Employment in Western Industrialized Nations, International Journal of Sociology 31(2), 70-97.

Metzger, G. (2006): Afterlife - Who Takes Heart for Restart?, ZEW Discussion Paper 06038, Mannheim.

Minniti, M., and C. Nardone (2007): Being in Someone Else's Shoes: the Role of Gender in Nascent Entrepreneurship, Small Business Economics 28, 223-238.

Niefert, M. (2010); Characteristics and Determinants of Start-ups from Unemployment: Evidence from German Micro Data, Journal of Small Business and Entrepreneurship, forthcoming. 
Oaxaca, R. (1973): Male-Female Wage Differentials in Urban Labor Markets, International Economic Review 14, 693-709.

Oaxaca, R., and M. Ransom (1994): On Discrimination and the Decomposition of Wage Differentials, Journal of Econometrics 61, 5-21.

Renzulli, L. A., H. Aldrich, and J. Moody (1999): Family Matters: Gender, Networks, and Entrepreneurial Outcomes, Social Forces 79(2), 523-546.

Robinson, P. B., and E. A. Sexton (1994): The Effect of Education and Experience on SelfEmployment Success, Journal of Business Venturing 9, 141-156.

Sarasvathy, S. D., N. Dew, S. R. Velamuri, and S. Venkataraman (2003): Three Views of Entrepreneurial Opportunity, in: Z. J. Acs and D. B. Audretsch (eds.), Handbook of Entrepreneurship Research, pp. 141-160, Kluwer, New York.

Schumpeter, J. A. (1934): Theorie der wirtschaftlichen Entwicklung: eine Untersuchung über Unternehmergewinn, Kapital, Kredit, Zins und den Konjunkturzyklus, 8th ed., reprint of 4th ed., Duncker \& Humblot, Berlin.

Schwartz, E. B. (1976): Entrepreneurship: A New Female Frontier, Journal of Contemporary Business (Winter), 47-76.

Sexton, D. L., and N. Bowman-Upton (1990): Female and male entrepreneurs: Psychological characteristics and their role in gender-related discrimination, Journal of Business Venturing 5(1), 29-36.

Shane, S. A. (2003): A general theory of entrepreneurship: The individual-opportunity nexus, Edward Elgar, Northampton, MA.

Silber, J., and M. Weber (1999): Labour market discrimination: are there significant differences between the various decomposition procedures?, Applied Economics 31(3), 359-365.

Sternberg, R., U. Brixy, and C. Hundt (2007): Global Entrepreneurchip Monitor (GEM) Länderbericht Deutschland 2006, Global Entrepreneurship Research Association, Hannover/Nürnberg, March.

Strohmeyer, R. (2004): Berufliche Ausbildung und Gründungsaktivitäten im Geschlechtervergleich, in: R. Leicht and F. Welter (eds.), Gründerinnen und selbständige Frauen. Potentiale, Strukturen und Entwicklungen in Deutschland, Karlsruhe, pp. 97-118.

Strohmeyer, R. and V. Tonoyan (2008): Employment Growth and Firm Innovativeness in Women- and Men-Owned Small Firms in Germany: An Effect of Endowments?, Paper presented at the the Workshop „Gender and the Labor Market“ at the ZEW Mannheim, March 2008.

Tchouvakhina, M. (2004): Gründungsbesonderheiten von Frauen - Ergebnisse einer explorativen Studie, in: KfW Bankengruppe (eds.), Chefinnensache - Frauen in der unternehmerischen Praxis, Physica, Heidelberg, pp. 83-108. 
Tchouvakhina, M., and C. Hofmann (2003/04): The KfW Start-up Monitor - An Instrument for In-Depth Analysis of Start-up Activity in Germany, RWI: Mitteilungen, 54/55(34), 267-285.

Tchouvakhina, M., and P. Tilleßen (2006): Unternehmensgründungen durch Frauen in Deutschland: Ergebnisse des KfW-Gründungsmonitors, FINANZ BETRIEB 8(2), 125128.

Thaler, R. H. (2000): From Homo Economicus to Homo Sapiens, Journal of Economic Perspectives 14, 133-141.

Tonoyan, V., R. Strohmeyer, and M. Habib (2008): Gender Gap in Potential Entrepreneurship: The Effects of Segregation and Job Characteristics, Paper presented at the Academy of Management Meeting, August 2008.

Van Praag, B. M. S., and A. S. Booij (2003), Risk Aversion and the Subjective Time Discount Rate: A Joint Approach, CESifo Working Paper 923, München.

Verheul, I., A. van Stel, and R. Thurik (2004): Explaining Female and Male Entrepreneurship across 29 Countries, SCALES Working Paper Nr. 200403.

Verheul, I., and R. Thurik (2001): Start-up capital: Does Gender Matter?, Small Business Economics 16(4), 329-345.

Wagner, J. (2007): What a Difference a Y Makes - Female and Male Nascent Entrepreneurs in Germany, Small Business Economics 28, 1-21.

Werner, A., and R. Kay (2006): Entrepreneurial Image, Gender, and the Formation of New Ventures, Die Betriebswirtschaft 66 (5), 497-520.

Wilson, F., J. Kickul, and D. Marlino (2007): Gender, entrepreneurial self-efficacy, and entrepreneurial career intentions: Implications for entrepreneurship education, Entrepreneurship Theory and Practice 31(3), 387-406.

Zapalska, A. (1997): A profile of woman entrepreneurs and enterprises in Poland, Journal of Small Business Management 35(4), 76-82. 


\section{Appendix A: Decomposition Analysis}

\section{A.1 Regression Notation of Start-Up Decision}

Estimating binary choice models has become commonplace in the empirical literature. Our subsequent exposition of decomposition analyses uses the following notation. Consider the individual start-up decision

(A1) $y_{i}=I\left(y_{i}^{*} \geq 0\right)=\left\{\begin{array}{ll}1 & \text { if } y_{i}^{*} \geq 0 \\ 0 & \text { if } y_{i}^{*}<0\end{array}\right.$,

where the latent start-up propensity $y_{i}^{*}$ of individuals $i=1, \ldots, N$ is a function of sociodemographic characteristics $Z_{i}$ and personality traits $W_{i}$ :

(A2) $y_{i}^{*}=Z_{i} \beta_{Z}+W_{i} \beta_{W}+u_{i}=X_{i} \beta+u_{i}$.

Given the probit assumption that the error term $u_{i}$ is normally distributed, the parameters $\beta$ of the conditional start-up probability

(A3) $\operatorname{Pr}\left(y_{i}=1 \mid X_{i}\right)=\operatorname{Pr}\left(y_{i}^{*} \geq 0 \mid X_{i}\right)=\Phi\left(Z_{i} \beta_{Z}+W_{i} \beta_{W}\right)=\Phi\left(X_{i} \beta\right)$

can be estimated via maximum likelihood.

\section{A.2 Blinder-Oaxaca-Type Decomposition}

The decompositions defined in equation (2) write:

$$
\begin{aligned}
\hat{Y}^{m}-\hat{Y}^{f}=\left(\hat{Y}^{m}-\hat{Y}_{m}^{f}\right)+\left(\hat{Y}_{m}^{f}-\hat{Y}^{f}\right) \\
=\underbrace{N_{m}^{-1} \sum_{i=1}^{N_{m}} \Phi\left(X_{i}^{m} \hat{\beta}^{m}\right)-N_{f}^{-1} \sum_{i=1}^{N_{f}} \Phi\left(X_{i}^{f} \hat{\beta}^{m}\right)}_{\text {characteristics effect }}+\underbrace{N_{f}^{-1} \sum_{i=1}^{N_{f}} \Phi\left(X_{i}^{f} \hat{\beta}^{m}\right)-N_{f}^{-1} \sum_{i=1}^{N_{f}} \Phi\left(X_{i}^{f} \hat{\beta}^{f}\right)}_{\text {coefficients effect }}
\end{aligned}
$$

and

$$
\begin{aligned}
\hat{Y}^{m}-\hat{Y}^{f}=\left(\hat{Y}_{f}^{m}-\hat{Y}^{f}\right)+\left(\hat{Y}^{m}-\hat{Y}_{f}^{m}\right) \\
=N_{m}^{-1} \underbrace{\sum_{i=1}^{N_{m}} \Phi\left(X_{i}^{m} \hat{\beta}^{f}\right)-N_{f}^{-1} \sum_{i=1}^{N_{f}} \Phi\left(X_{i}^{f} \hat{\beta}^{f}\right)}_{\text {characteristics effect }}+\underbrace{N_{m}^{-1} \sum_{i=1}^{N_{m}} \Phi\left(X_{i}^{m} \hat{\beta}^{m}\right)-N_{m}^{-1} \sum_{i=1}^{N_{m}} \Phi\left(X_{i}^{m} \hat{\beta}^{f}\right)}_{\text {coefficients effect }},
\end{aligned}
$$

respectively. In contrast to the approach pursued by Fairlie (1999, 2005), we do not focus on the difference in observed average probabilities $\left(\bar{Y}^{m}-\bar{Y}^{f}\right)$, but rather on the projected difference $\left(\hat{Y}^{m}-\hat{Y}^{f}\right)$. The advantage of this approach is that the coefficient effect includes less residual noise. Even though $\bar{Y}^{g}$ and $\hat{Y}^{g}$ resulting from the probit estimation are not necessarily identical, their deviation is negligible for appropriate model specifications. 
Counterfactuals are easily computed using the characteristics of one gender and the coefficients estimated for the other.

\section{A.3 Extended Decomposition Using Mahalanobis Distance Matching}

In addition to the classical decomposition into characteristics and coefficients effect, equation (3) decomposes the gender gap in estimated entrepreneurial activities into five separate components.

In order to take into account the correlation between socio-demographics and personality traits when constructing the counterfactuals, we do not follow Fairlie (2005) but perform a covariate matching with respect to $W$ and choose the Mahalanobis metric as a distance measure between males' and females' personality traits. The Mahalanobis matching assigns to each women in the sample a men with similar personality traits. Thereafter, we use the sociodemographic characteristics of the matched males and females' personality traits for our decomposition of the gender gap into separate components.

More specifically, the components introduced in equations (4) to (8) write

$$
\begin{aligned}
& \Delta 1=N_{m}^{-1} \sum_{i=1}^{N_{m}} \Phi\left(\hat{\beta}_{0}^{f}+Z_{i}^{m} \hat{\beta}_{Z}^{f}+W_{i}^{f} \hat{\beta}_{W}^{f}\right)-N_{f}^{-1} \sum_{i=1}^{N_{f}} \Phi\left(\hat{\beta}_{0}^{f}+Z_{i}^{f} \hat{\beta}_{Z}^{f}+W_{i}^{f} \hat{\beta}_{W}^{f}\right), \\
& \Delta 2=N_{m}^{-1} \sum_{i=1}^{N_{m}} \Phi\left(\hat{\beta}_{0}^{f}+Z_{i}^{m} \hat{\beta}_{Z}^{f}+W_{i}^{m} \hat{\beta}_{W}^{f}\right)-N_{m}^{-1} \sum_{i=1}^{N_{m}} \Phi\left(\hat{\beta}_{0}^{f}+Z_{i}^{m} \hat{\beta}_{Z}^{f}+W_{i}^{f} \hat{\beta}_{W}^{f}\right), \\
& \Delta 3=N_{m}^{-1} \sum_{i=1}^{N_{m}} \Phi\left(\hat{\beta}_{0}^{m}+Z_{i}^{m} \hat{\beta}_{Z}^{f}+W_{i}^{m} \hat{\beta}_{W}^{f}\right)-N_{m}^{-1} \sum_{i=1}^{N_{m}} \Phi\left(\hat{\beta}_{0}^{f}+Z_{i}^{m} \hat{\beta}_{Z}^{f}+W_{i}^{m} \hat{\beta}_{W}^{f}\right), \\
& \Delta 4=N_{m}^{-1} \sum_{i=1}^{N_{m}} \Phi\left(\hat{\beta}_{0}^{m}+Z_{i}^{m} \hat{\beta}_{Z}^{f}+W_{i}^{m} \hat{\beta}_{W}^{m}\right)-N_{m}^{-1} \sum_{i=1}^{N_{m}} \Phi\left(\hat{\beta}_{0}^{m}+Z_{i}^{m} \hat{\beta}_{Z}^{f}+W_{i}^{m} \hat{\beta}_{W}^{f}\right), \text { and } \\
& \Delta 5=N_{m}^{-1} \sum_{i=1}^{N_{m}} \Phi\left(\hat{\beta}_{0}^{m}+Z_{i}^{m} \hat{\beta}_{Z}^{m}+W_{i}^{m} \hat{\beta}_{W}^{m}\right)-N_{m}^{-1} \sum_{i=1}^{N_{m}} \Phi\left(\hat{\beta}_{0}^{m}+Z_{i}^{m} \hat{\beta}_{Z}^{f}+W_{i}^{m} \hat{\beta}_{W}^{m}\right) .
\end{aligned}
$$

Standard errors of the estimated decomposition effects are obtained from a parametric bootstrap with 100 redraws from the estimated distribution of the parameters $\beta^{g}=\left(\beta_{Z}^{\prime g}, \beta_{W}^{\prime g}\right)^{\prime}$. 


\section{Appendix B: Tables and Figures}

\section{Table B.1: Definition of Variables}

\begin{tabular}{|c|c|}
\hline $\begin{array}{c}\text { Variable } \\
\text { [number of regressors] }\end{array}$ & Definition \\
\hline entrepreneur & dummy with 1 = persons who started (full-time or part-time) self-employment within the last 12 months \\
\hline gender [1] & dummy with 1 = female \\
\hline age [5] & dummies for age groups: $18-24,25-34,35-44,45-54,55-64$ years \\
\hline education [7] & $\begin{array}{l}\text { dummies for: no formal degree, vocational training degree (Lehrabschluss), vocational school graduation (Berufsfachschulabschluss), } \\
\text { technical school graduation (Fachschule/Meisterschule), technical college degree (Fachhochschulabschluss), university degree, } \\
\text { other degree (civil service education, other unspecified degrees) }\end{array}$ \\
\hline professional status [9] & $\begin{array}{l}\text { dummies for: chief executive officer, executive employee, other white-collar employee, civil servant, skilled blue-collar worker, } \\
\text { other blue-collar worker, self-employed, unemployed, out of labor force }\end{array}$ \\
\hline city size [5] & dummies for: up to 5,000, > 5,000-20,000, > 20,000-100,000, > 100,000-500,000, > 500,000 inhabitants \\
\hline region [1] & dummy with 1 = living in Eastern Germany \\
\hline foreigner [1] & dummy with 1 = origin in foreign country \\
\hline household size[5] & dummies for: one-/two-/three-/four-/five-person household \\
\hline head of household [1] & dummy with 1 = person running the household \\
\hline children aged 14 or under [1] & dummy with $1=$ at least one child aged 14 or younger living in the household \\
\hline personality traits [8] & see Table B.2 \\
\hline attitudes towards entrepreneurship [5] & see Table B.2 \\
\hline
\end{tabular}

Data source: KfW Start-up Monitor, 2007. 
Table B.2: Personality Traits and Attitudes towards Entrepreneurship

\begin{tabular}{|c|c|c|}
\hline Item & Statement & Variable \\
\hline \multicolumn{3}{|c|}{ A: Personality Traits } \\
\hline$(1)$ & "Financial security is of central importance to me." & risk tolerance \\
\hline$(2)$ & "I feel most comfortable if life happens in due process." & openness \\
\hline (3) & "I quickly comprehend complex or complicated issues.“ & cognitive skills \\
\hline (4) & "I am willing to put extraordinary efforts in my personal and professional advancement.“ & need for achievement \\
\hline (6) & "Expressing my views and ideas to my environment is difficult for me." & persuasiveness \\
\hline (7) & "I often develop and implement new ideas.“ & creativity \\
\hline$(8)$ & "If something goes wrong, I say to myself: 'Now more than ever!'“ & determination \\
\hline \multicolumn{3}{|c|}{ B: Attitudes towards Entrepreneurship } \\
\hline (9) & "Starting a business is an attractive opportunity for my personal career development." & desirability of self-employment \\
\hline$(10)$ & "Current economic and political conditions offer good opportunities for starting a business." & suitability of current economic conditions \\
\hline$(12)$ & "My current life circumstances are well suited for starting a business.” & suitability of personal live circumstances \\
\hline (13) & "I have the personal and professional skills necessary for a successful business start-up." & entrepreneurial aptitude \\
\hline
\end{tabular}

Persons assessed the above statements on a Likert scale ranging from one ('I fully agree') to five ('I fully disagree').

We rescaled the answers by means of linear transformation to range from 0 (minimum approval) to 100 (maximum approval of the respective notion).

The transformation is $\mathrm{y}=(125-25 \mathrm{x})$ for items (1), (2), (5), and (6), and $\mathrm{y}=(-25+25 \mathrm{x})$ for all other items. Data source: KfW Start-up Monitor, 2007. 


\section{Tables and Figures to Be Placed in the Text}

Figure 1: Share of Female Entrepreneurs

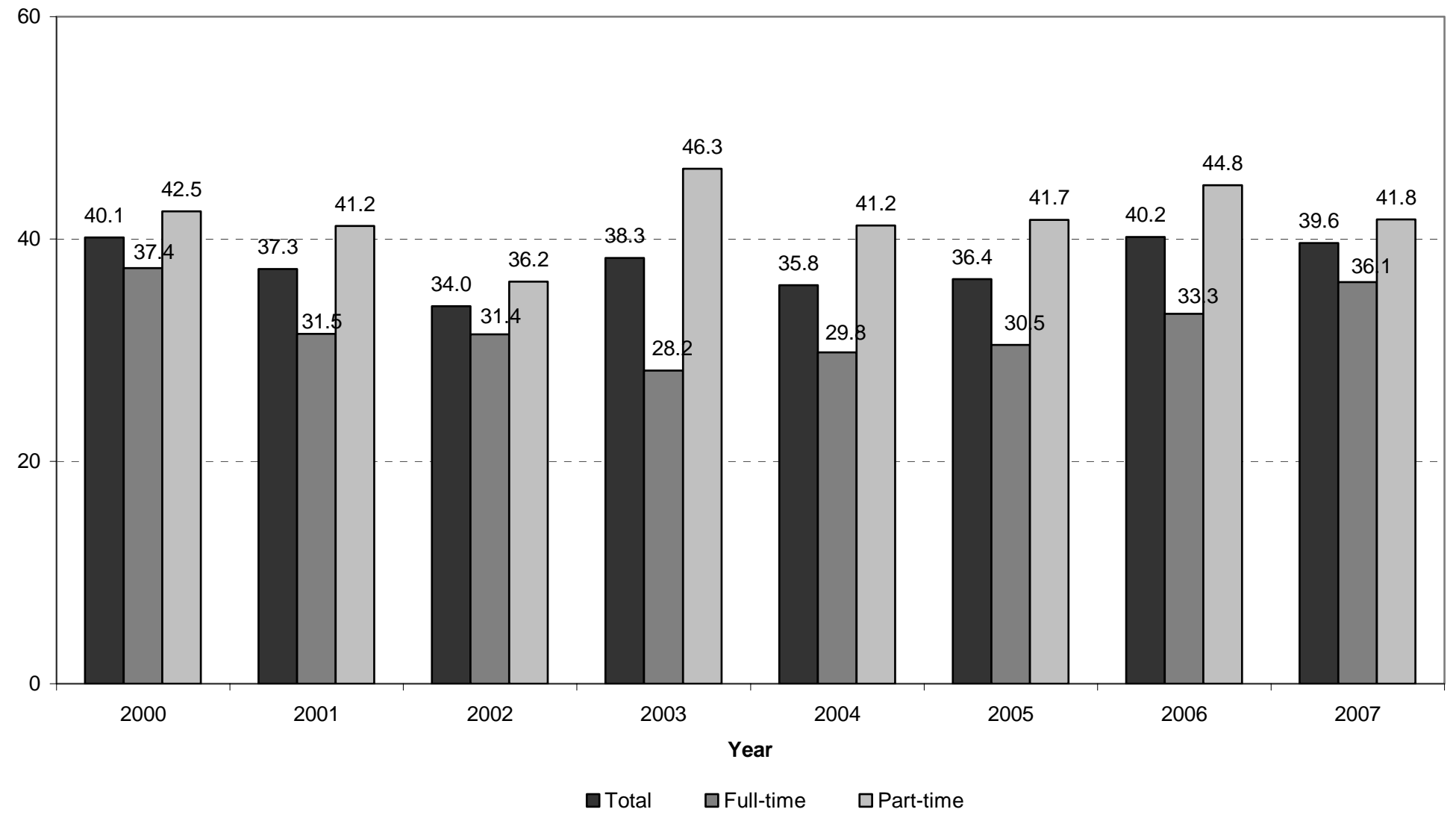

Female entrepreneurs (total/full-time/part-time) as percentage of all entrepreneurs (total/full-time/part-time), population-weighted. Data source: KfW Start-up Monitor, 2007. 
Table 1: Characteristics of Entrepreneurs and Non-Entrepreneurs, by Gender

\begin{tabular}{|c|c|c|c|c|c|c|}
\hline & \multicolumn{3}{|c|}{ "entrepreneurs } & \multicolumn{3}{|c|}{ non-entrepreneurs } \\
\hline & (1) & (2) & (3) & (4) & (5) & (6) \\
\hline & males & females & $\begin{array}{c}\text { significance } \\
(1)-(2)\end{array}$ & males & & $\begin{array}{c}\text { significance } \\
\text { (4)-(5) }\end{array}$ \\
\hline \multicolumn{7}{|l|}{ age } \\
\hline 18 to 24 years & 19.61 & 15.11 & $*$ & 13.19 & 11.64 & $* *$ \\
\hline 25 to 34 years & 30.81 & 26.78 & & 18.43 & 16.85 & $*$ \\
\hline 35 to 44 years & 27.18 & 33.44 & $*$ & 27.73 & 24.53 & $* * *$ \\
\hline 45 to 54 years & 13.41 & 17.93 & $*$ & 22.09 & 25.36 & $* * *$ \\
\hline 55 to 64 years & 8.99 & 6.74 & & 18.56 & 21.62 & $* * *$ \\
\hline \multicolumn{7}{|l|}{ education } \\
\hline no degree & 14.84 & 15.16 & & 13.62 & 16.02 & $* * *$ \\
\hline vocational training & 37.88 & 38.13 & & 47.04 & 51.34 & $* * *$ \\
\hline vocational school & 7.17 & 9.74 & & 7.69 & 11.13 & $* * *$ \\
\hline technical school & 13.22 & 8.15 & $* *$ & 13.11 & 6.73 & $* * *$ \\
\hline technical college & 10.38 & 11.35 & & 7.63 & 5.98 & $* * *$ \\
\hline university & 14.34 & 14.42 & & 7.88 & 6.52 & $* *$ \\
\hline other degree & 2.16 & 3.05 & & 3.04 & 2.29 & $* *$ \\
\hline \multicolumn{7}{|l|}{ professional status } \\
\hline chief executive officer & 0.56 & 0.06 & & 1.18 & 1.07 & \\
\hline executive employee & 11.18 & 6.50 & $* *$ & 14.53 & 8.08 & $* * *$ \\
\hline other white-collar employee & 9.65 & 23.90 & $* * *$ & 19.19 & 32.53 & $* * *$ \\
\hline civil servant & 3.61 & 2.01 & & 5.56 & 3.27 & $* * *$ \\
\hline skilled blue-collar worker & 5.71 & 0.98 & $* * *$ & 16.15 & 2.35 & $* * *$ \\
\hline other blue-collar worker & 1.97 & 3.06 & & 6.39 & 6.34 & \\
\hline self-employed & 44.69 & 34.76 & $* * *$ & 9.82 & 3.17 & $* * *$ \\
\hline unemployed & 6.59 & 3.57 & $*$ & 9.31 & 7.80 & $* *$ \\
\hline out of labor force & 16.04 & 25.17 & $* * *$ & 17.87 & 35.38 & $* * *$ \\
\hline \multicolumn{7}{|l|}{ city size } \\
\hline up to 5,000 inhabitants & 12.74 & 20.32 & $* * *$ & 18.82 & 18.94 & \\
\hline$>5,000$ to 20,000 inhabitants & 26.94 & 24.64 & & 26.02 & 27.85 & $*$ \\
\hline$>20,000$ to 100,000 inhabitants & 23.49 & 20.86 & & 25.80 & 26.02 & \\
\hline$>100,000$ to 500,000 inhabitants & 17.56 & 17.54 & & 17.03 & 14.44 & $* * *$ \\
\hline
\end{tabular}




\begin{tabular}{|c|c|c|c|c|c|c|}
\hline$>500,000$ inhabitants & 19.27 & 16.64 & & 12.34 & 12.74 & \\
\hline region (= Eastern Germany) & 19.64 & 14.11 & $* *$ & 20.82 & 19.82 & \\
\hline foreign origin & 12.59 & 8.57 & * & 8.41 & 9.09 & \\
\hline \multicolumn{7}{|l|}{ household size } \\
\hline one-person household & 18.84 & 11.36 & $* * *$ & 21.46 & 13.12 & $* * *$ \\
\hline two-person household & 32.35 & 30.69 & & 30.59 & 33.94 & $* * *$ \\
\hline three-person household & 20.80 & 25.10 & & 21.43 & 24.21 & $* * *$ \\
\hline four-person household & 18.81 & 20.74 & & 16.13 & 17.78 & $*$ \\
\hline five-person household & 9.20 & 12.10 & & 10.40 & 10.94 & \\
\hline running the household & 45.39 & 76.85 & $* * *$ & 45.68 & 83.24 & $* * *$ \\
\hline children aged 14 or under & 23.21 & 30.51 & $* *$ & 23.08 & 28.14 & $* * *$ \\
\hline \multicolumn{7}{|l|}{ personality traits } \\
\hline risk tolerance & 23.29 & 20.33 & & 19.37 & 16.07 & $* * *$ \\
\hline openness & 38.23 & 37.69 & & 30.16 & 27.51 & $* * *$ \\
\hline cognitive skills & 76.94 & 73.46 & $* *$ & 71.94 & 69.37 & $* * *$ \\
\hline need for achievement & 86.16 & 77.33 & $* * *$ & 74.81 & 69.28 & $* * *$ \\
\hline emotional stability & 47.28 & 50.76 & & 48.88 & 51.52 & $* * *$ \\
\hline persuasiveness & 65.43 & 68.15 & & 61.06 & 60.59 & \\
\hline creativity & 69.42 & 68.22 & & 57.84 & 55.30 & $* * *$ \\
\hline determination & 75.00 & 77.55 & & 73.01 & 74.62 & $* * *$ \\
\hline \multicolumn{7}{|l|}{ attitude towards entrepreneurship } \\
\hline desirability of self-employment & 71.03 & 68.48 & & 40.11 & 28.11 & $* * *$ \\
\hline suitability of economic conditions & 45.31 & 40.73 & $* *$ & 39.07 & 30.86 & $* * *$ \\
\hline entrepreneurs’ reputation & 54.71 & 50.73 & $* *$ & 56.31 & 59.41 & $* *$ \\
\hline suitability of personal circumstances & 65.26 & 63.37 & & 30.72 & 19.95 & $* * *$ \\
\hline entrepreneurial aptitude & 77.01 & 74.19 & & 50.61 & 39.05 & $* * *$ \\
\hline number of observations (min./max.) & $413 / 429$ & $343 / 368$ & & $3,004 / 3,084$ & $4,037 / 4,131$ & \\
\hline
\end{tabular}

Shares in percent, population-weighted. Personality traits and attitudes: average values, population-weighted.

Significances: Tests for equal proportions, mean-comparison tests (personality traits and attitudes).

*,**,*** significant at $10 \%, 5 \%, 1 \%$ level.

Data source: KfW Start-up Monitor, 2007. 
Table 2: Determinants of the Start-Up Decision, Pooled Probit Estimations

\begin{tabular}{|c|c|c|c|c|c|c|c|c|}
\hline \multirow[b]{3}{*}{ gender (= female) } & \multicolumn{2}{|c|}{$\begin{array}{c}(1) \\
\text { gender dummy } \\
\text { [full sample] }\end{array}$} & \multicolumn{2}{|c|}{$\begin{array}{c}(2) \\
\text { gender dummy } \\
\text { [estimation sample] }\end{array}$} & \multicolumn{2}{|c|}{$\begin{array}{c}\text { (3) } \\
\text { plus } \\
\text { socio-demographics }\end{array}$} & \multicolumn{2}{|c|}{$\begin{array}{c}\text { (4) } \\
\text { plus } \\
\text { personality traits }\end{array}$} \\
\hline & $\mathrm{dP} / \mathrm{dX}$ & \multirow{2}{*}{$\begin{array}{l}\text { std. error } \\
(0.0015)\end{array}$} & \multirow{2}{*}{$\frac{\mathrm{dP} / \mathrm{dX}}{-0.0342 * * *}$} & \multirow{2}{*}{$\frac{\text { std. error }}{(0.0063)}$} & \multirow{2}{*}{$\frac{\mathrm{dP} / \mathrm{dX}}{-0.0284 * * *}$} & \multirow{2}{*}{$\frac{\text { std. error }}{(0.0065)}$} & \multirow{2}{*}{$\frac{\mathrm{dP} / \mathrm{dX}}{-0.0257 * * *}$} & \multirow{2}{*}{$\begin{array}{c}\text { std. error } \\
(0.0064)\end{array}$} \\
\hline & $-0.0090 * * *$ & & & & & & & \\
\hline \multicolumn{9}{|l|}{ age (ref.: 35 to 44 years) } \\
\hline 18 to 24 years & & & & & 0.0074 & $(0.0130)$ & -0.0037 & $(0.0126)$ \\
\hline 25 to 34 years & & & & & $0,0286 * * *$ & $(0,0043)$ & $0,0240 * * *$ & $(0,0095)$ \\
\hline 45 to 54 years & & & & & $-0,0247 * * *$ & $(0.0099)$ & $-0.0213 * * *$ & $(0.0084)$ \\
\hline 55 to 64 years & & & & & $-0.0483 * * *$ & $(0.0084)$ & $-0.0422 * * *$ & $(0.0100)$ \\
\hline \multicolumn{9}{|l|}{ education (ref.: vocational training) } \\
\hline no degree & & & & & 0.0148 & $(0.0124)$ & 0.0112 & $(0.0120)$ \\
\hline vocational school & & & & & 0.0103 & $(0.0137)$ & 0.0058 & $(0.0130)$ \\
\hline technical school & & & & & $0.0428 * * *$ & $(0.0155)$ & $0.0321 * *$ & $(0.0144)$ \\
\hline technical college & & & & & $0.0645 * * *$ & $(0.0151)$ & $0.0506 * * *$ & $(0.0140)$ \\
\hline university & & & & & $0.0854 * * *$ & $(0.0153)$ & $0.0585 * * *$ & $(0.0137)$ \\
\hline other degree & & & & & $0.0860 * * *$ & $(0.0311)$ & $0.0678 * * *$ & $(0.0294)$ \\
\hline \multicolumn{9}{|c|}{ professional status (ref.:other w.-c. empl.) } \\
\hline chief executive officer & & & & & 0.0127 & $(0.0255)$ & -0.0074 & $(0.0208)$ \\
\hline executive employee & & & & & 0.0116 & $(0.0107)$ & -0.0044 & $(0.0097)$ \\
\hline civil servant & & & & & $-0.0458 * * *$ & $(0.0118)$ & $-0.0428 * * *$ & $(0.0117)$ \\
\hline skilled blue-collar worker & & & & & $-0.0251 *$ & $(0.0131)$ & $-0.0240 *$ & $(0.0128)$ \\
\hline other blue-collar worker & & & & & $-0.0282 *$ & $(0.0146)$ & -0.0172 & $(0.0157)$ \\
\hline self-employed & & & & & $0.0239 *$ & $(0.0150)$ & -0.0010 & $(0.0127)$ \\
\hline unemployed & & & & & $0.0986 * * *$ & $(0.0195)$ & $0.0958 * * *$ & $(0.0195)$ \\
\hline out of labor force & & & & & $0.0243 * *$ & $(0.0106)$ & $0.0251 * *$ & $(0.0107)$ \\
\hline \multicolumn{9}{|l|}{ city size (ref.: > 500,000 inhabitants) } \\
\hline up to 5,000 inhabitants & & & & & -0.0117 & $(0.0105)$ & -0.0091 & $(0.0104)$ \\
\hline$>5,000$ to 20,000 inhabitants & & & & & -0.0117 & $(0.0096)$ & -0.0002 & $(0.0096)$ \\
\hline$>20,000$ to 100,000 inhabitants & & & & & -0.0091 & $(0.0093)$ & -0.0085 & $(0.0093)$ \\
\hline$>100,000$ to 500,000 inhabitants & & & & & -0.0087 & $(0.0099)$ & -0.0109 & $(0.0097)$ \\
\hline region (= Eastern Germany) & & & & & $-0.0233 * * *$ & $(0.0075)$ & $-0.0199 *$ & $(0.0074)$ \\
\hline foreign origin & & & & & 0.0120 & $(0.0118)$ & 0.0186 & $(0.0126)$ \\
\hline
\end{tabular}




\begin{tabular}{|c|c|c|c|c|c|c|}
\hline $\begin{array}{l}\text { household size (ref.: one-person househol } \\
\text { two-person household }\end{array}$ & & & 0.0055 & $(0.0096)$ & 0.0038 & $(0.0093)$ \\
\hline three-person household & & & 0.0001 & $(0.0110)$ & 0.0023 & $(0.0109)$ \\
\hline four-person household & & & 0.0049 & $(0.0120)$ & 0.0020 & $(0.0116)$ \\
\hline five-person household & & & -0.0051 & $(0.0136)$ & -0.0073 & $(0.0131)$ \\
\hline running the household & & & 0.0023 & $(0.0077)$ & 0.0044 & $(0.0076)$ \\
\hline children aged 14 or under & & & 0.0021 & $(0.0086)$ & 0.0062 & $(0.0090)$ \\
\hline \multicolumn{7}{|l|}{ personality traits } \\
\hline risk tolerance & & & & & 0.0047 & $(0.0031)$ \\
\hline openness & & & & & $0.0110 * * *$ & $(0.0033)$ \\
\hline cognitive skills & & & & & 0.0015 & $(0.0035)$ \\
\hline need for achievement & & & & & $0.0185 * * *$ & $(0.0041)$ \\
\hline emotional stability & & & & & -0.0041 & $(0.0030)$ \\
\hline persuasiveness & & & & & $0.0053 *$ & $(0.0032)$ \\
\hline creativity & & & & & $0.0273 * * *$ & $(0.0040)$ \\
\hline determination & & & & & 0.0016 & $(0.0033)$ \\
\hline number of observations & 37,620 & 8,717 & \multicolumn{2}{|c|}{8,395} & \multicolumn{2}{|c|}{8,273} \\
\hline observed probability & 0.0212 & 0.0914 & \multicolumn{2}{|c|}{0.0883} & \multicolumn{2}{|c|}{0.0885} \\
\hline estimated probability of reference person & 0.0263 & 0.1104 & \multicolumn{2}{|c|}{0.0798} & \multicolumn{2}{|c|}{0.0764} \\
\hline pseudo $\mathrm{R}^{2}$ & 0.005 & 0.006 & \multicolumn{2}{|c|}{0.060} & \multicolumn{2}{|c|}{0.085} \\
\hline log likelihood & $-3,842.5$ & $-2,650.9$ & \multicolumn{2}{|c|}{$-2,356.6$} & \multicolumn{2}{|c|}{$-2,264.2$} \\
\hline
\end{tabular}

$*, * *, * * *$ significant at $10 \%, 5 \%, 1 \%$ level, heteroscedasticity-consistent standard errors in parentheses.

Coefficients report ceteris paribus effects of changes from 0 to 1 (dummy variables) or increases by one standard deviation (personality traits), respectively. The reference person has (full-sample) mean personality traits (specification (4)).

Data source: KfW Start-up Monitor, 2007. 
Table 3: Determinants of Start-Up Decisions, Gender-Specific Probit Estimations

\begin{tabular}{|c|c|c|c|c|c|c|}
\hline & \multicolumn{2}{|c|}{ socio-demographics } & \multicolumn{2}{|c|}{ plus personality traits } & \\
\hline & $\begin{array}{c}\text { males } \\
\mathrm{dP} / \mathrm{dX} \\
(1) \\
\end{array}$ & $\begin{array}{c}\text { females } \\
\mathrm{dP} / \mathrm{dX} \\
(2)\end{array}$ & $\begin{array}{c}\text { males } \\
\mathrm{dP} / \mathrm{dX} \\
(3) \\
\end{array}$ & $\begin{array}{c}\text { females } \\
\mathrm{dP} / \mathrm{dX} \\
(4)\end{array}$ & $\begin{array}{c}\text { Signif. of } \\
(1)-(2) \\
(5)\end{array}$ & $\begin{array}{c}\text { fferences } \\
\text { (3)-(4) } \\
(6)\end{array}$ \\
\hline \multicolumn{7}{|l|}{ age (ref.: 35 to 44 years) } \\
\hline 18 to 24 years & $\begin{array}{c}0.0284 * \\
(0.0180)\end{array}$ & $\begin{array}{r}-0.0209 \\
(0.0168)\end{array}$ & $\begin{array}{c}0.0291 * \\
(0.0190)\end{array}$ & $\begin{array}{r}-0.0192 \\
(0.0152)\end{array}$ & $* *$ & $* *$ \\
\hline 25 to 34 years & $\begin{array}{l}0.0449 * * * \\
(0.0140)\end{array}$ & $\begin{array}{r}0.0077 \\
(0.0121)\end{array}$ & $\begin{array}{l}0.0412 * * * \\
(0.0141)\end{array}$ & $\begin{array}{r}0.0063 \\
(0.0108)\end{array}$ & $* *$ & $* *$ \\
\hline 45 to 54 years & $\begin{array}{l}-0.0146 \\
(0.0094)\end{array}$ & $\begin{array}{l}-0.0302 \text { *** } \\
(0.0120)\end{array}$ & $\begin{array}{r}-0.0136 \\
(0.0102)\end{array}$ & $\begin{array}{l}-0.0238 * * * \\
(0.0108)\end{array}$ & & \\
\hline 55 to 64 years & $\begin{array}{l}-0.0161 \\
(0.0102)\end{array}$ & $\begin{array}{l}-0.0653 \text { *** } \\
(0.0184)\end{array}$ & $\begin{array}{r}-0.0124 \\
(0.0113)\end{array}$ & $\begin{array}{l}-0.0543 \text { *** } \\
(0.0166)\end{array}$ & $* * *$ & $* * *$ \\
\hline \multicolumn{7}{|c|}{ education (ref.: vocational training) } \\
\hline no degree & $\begin{array}{c}0.0233 * \\
(0.0160)\end{array}$ & $\begin{array}{r}0.0013 \\
(0.0160)\end{array}$ & $\begin{array}{r}0.0200 \\
(0.0161)\end{array}$ & $\begin{array}{l}-0.0003 \\
(0.0145)\end{array}$ & & \\
\hline vocational school & $\begin{array}{r}0.0091 \\
(0.0167)\end{array}$ & $\begin{array}{r}0.0107 \\
(0.0176)\end{array}$ & $\begin{array}{r}0.0083 \\
(0.0179)\end{array}$ & $\begin{array}{r}0.0053 \\
(0.0152)\end{array}$ & & \\
\hline technical school & $\begin{array}{l}0.0225 * \\
(0.0154)\end{array}$ & $\begin{array}{l}0.0628 * * * \\
(0.0260)\end{array}$ & $\begin{array}{r}0.0228 \\
(0.0165)\end{array}$ & $\begin{array}{l}0.0408 \text { ** } \\
(0.0217)\end{array}$ & & \\
\hline technical college & $\begin{array}{l}0.0374 \text { *** } \\
(0.0157)\end{array}$ & $\begin{array}{l}0.0859 * * * \\
(0.0244)\end{array}$ & $\begin{array}{l}0.0336 * * \\
(0.0162)\end{array}$ & $\begin{array}{l}0.0657 \text { *** } \\
(0.0211)\end{array}$ & & \\
\hline university & $\begin{array}{l}0.0575 * * * \\
(0.0172)\end{array}$ & $\begin{array}{l}0.0943 * * * \\
(0.0229)\end{array}$ & $\begin{array}{l}0.0425 * \\
(0.0162)\end{array}$ & $\begin{array}{l}0.0642 \text { *** } \\
(0.0197)\end{array}$ & & \\
\hline other degree & $\begin{array}{l}0.0675 * * \\
(0.0369)\end{array}$ & $\begin{array}{l}0.0844 \text { ** } \\
(0.0438)\end{array}$ & $\begin{array}{c}0.0703 * * \\
(0.0391)\end{array}$ & $\begin{array}{l}0.0527 * \\
(0.0378)\end{array}$ & & \\
\hline professional status (ref.: oth & & & & & & \\
\hline chief executive officer & $\begin{array}{r}0.0035 \\
(0.0246)\end{array}$ & $\begin{array}{r}0.0303 \\
(0.0435)\end{array}$ & $\begin{array}{r}-0.0112 \\
(0.0223)\end{array}$ & $\begin{array}{r}0.0088 \\
(0.0329)\end{array}$ & & \\
\hline executive employee & $\begin{array}{r}0.0137 \\
(0.0121)\end{array}$ & $\begin{array}{r}0.0082 \\
(0.0154)\end{array}$ & $\begin{array}{r}-0.0005 \\
(0.0116)\end{array}$ & $\begin{array}{l}-0.0055 \\
(0.0126)\end{array}$ & & \\
\hline civil servant & $\begin{array}{l}-0.0246 * \\
(0.0131)\end{array}$ & $\begin{array}{l}-0.0572 * * * \\
(0.0179)\end{array}$ & $\begin{array}{l}-0.0258 * \\
(0.0143)\end{array}$ & $\begin{array}{l}-0.0482 * * * \\
(0.0162)\end{array}$ & & \\
\hline skilled blue-collar worker & $\begin{array}{r}-0.0165 \\
(0.0123)\end{array}$ & $\begin{array}{l}-0.0445 \text { *** } \\
(0.0256)\end{array}$ & $\begin{array}{r}-0.0183 \\
(0.0133)\end{array}$ & $\begin{array}{l}-0.0386 \\
(0.0226)\end{array}$ & & \\
\hline
\end{tabular}


other blue-collar worker

self-employed

unemployed

out of labor force

city size (ref.: > 500,000 inhabitants)

up to 5,000 inhabitants

$>5,000$ to 20,000 inhabitants

$>20,000$ to 100,000 inhabitants

$>100,000$ to 500,000 inhabitants

region (= Eastern Germany)

\section{foreign origin}

household size (ref.: one-person household)

two-person household

three-person household

four-person household

five-person household

\section{running the household}

\section{children aged 14 or under}

\section{personality traits}

risk tolerance

openness

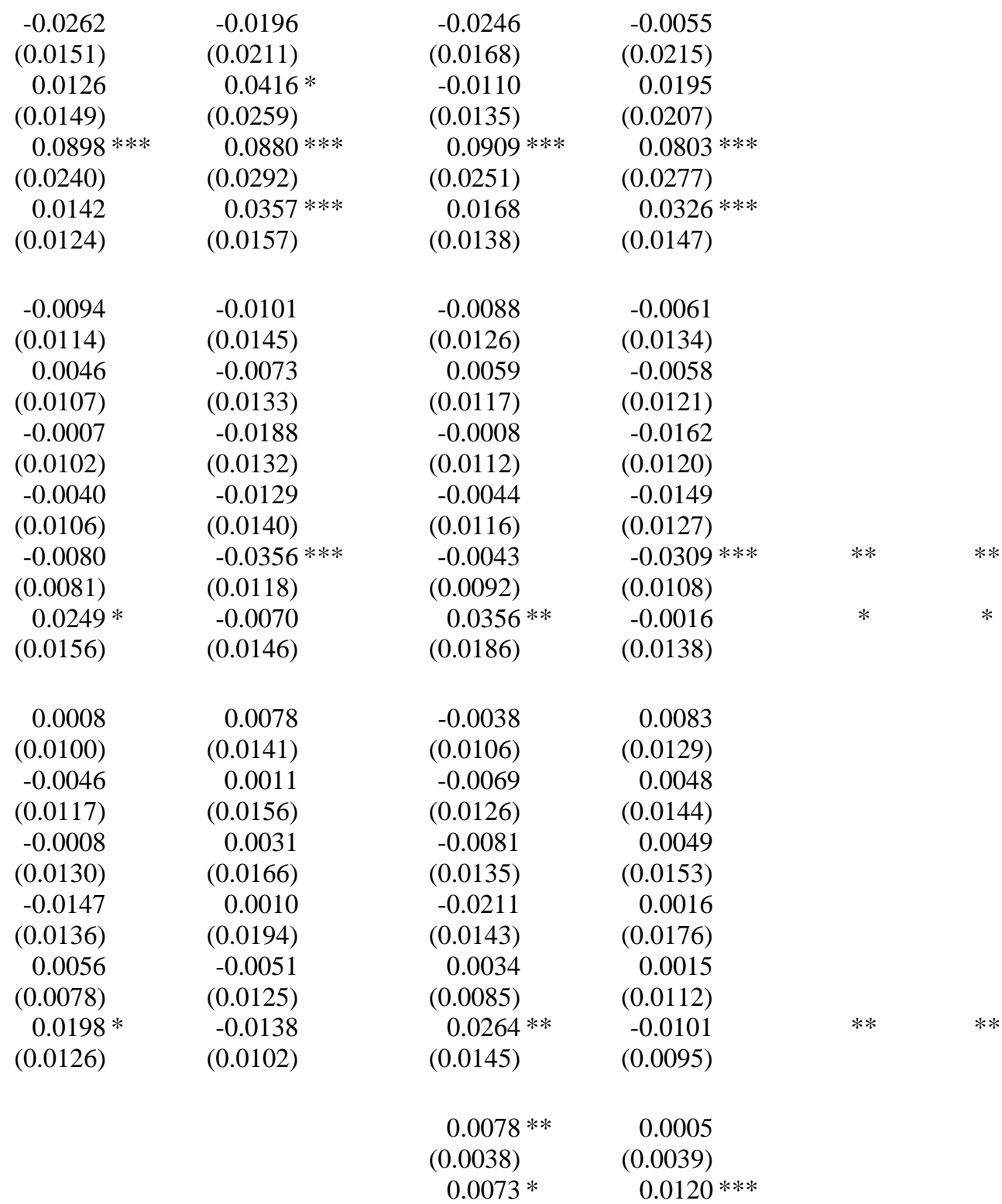




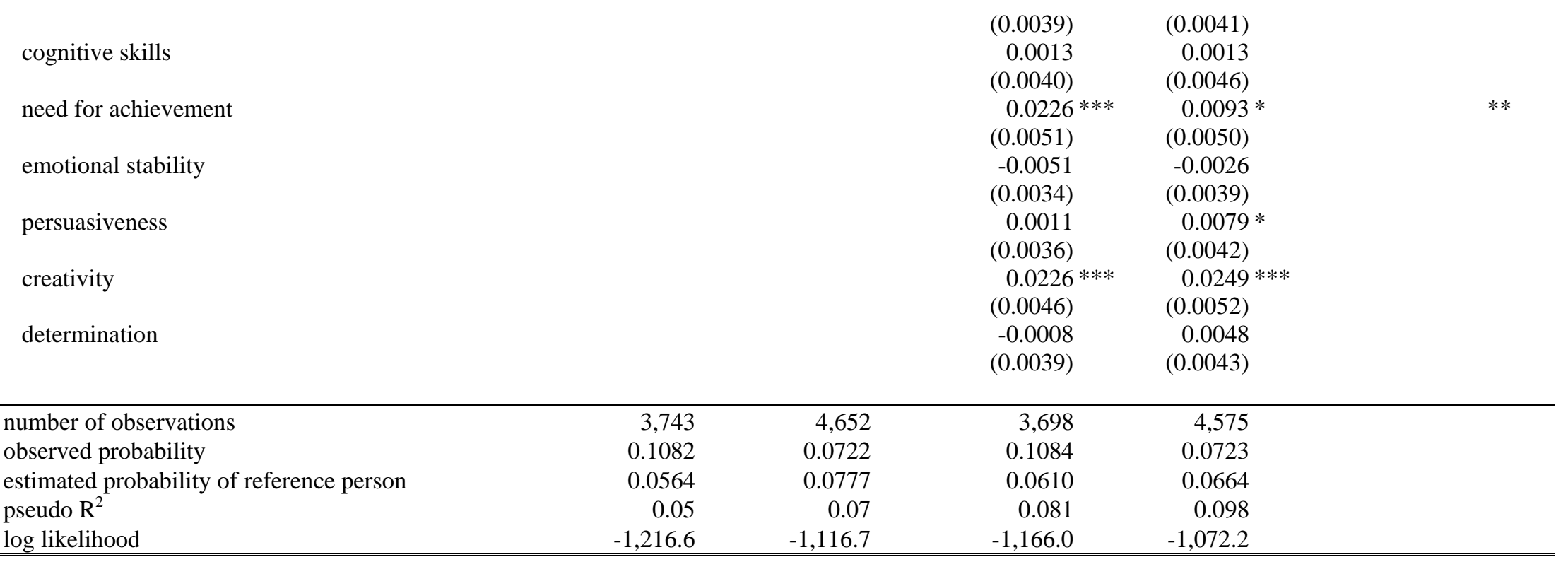

*,**,*** significant at $10 \%, 5 \%, 1 \%$ level, heteroscedasticity-consistent standard errors in parentheses.

Coefficients report ceteris paribus effects of changes from 0 to 1 (dummy variables) or increases by one standard deviation (personality traits), respectively.

The reference person has (gender-specific) mean personality traits (specifications (3) and (4)).

Data source: KfW Start-up Monitor, 2007. 
Table 4: Decomposition Analysis I: Characteristics and Coefficients Effects

\begin{tabular}{|c|c|c|c|c|}
\hline \multirow{3}{*}{$\begin{array}{l}\text { Predicted start-up propensity } \\
\text { males } \\
\text { females } \\
\text { difference } \\
\text { Counterfactual situation: equation }\end{array}$} & \multicolumn{2}{|c|}{$\begin{array}{c}\text { (A) } \\
\text { only socio-demographics }\end{array}$} & \multicolumn{2}{|c|}{$\begin{array}{c}\text { (B) } \\
\text { including personality traits }\end{array}$} \\
\hline & & & & \\
\hline & (A4) & (A5) & (A4) & (A5) \\
\hline characteristics effect & $\begin{array}{c}0.0006 \\
(0.0053) \\
1.7 \%\end{array}$ & $\begin{array}{c}0.0040 \\
(0.0045) \\
11.1 \%\end{array}$ & $\begin{array}{c}0.0079 \\
(0.0052) \\
21.9 \%\end{array}$ & $\begin{array}{c}0.0039 \\
(0.0043) \\
10.8 \%\end{array}$ \\
\hline coefficients effect & $\begin{array}{c}0.0355 \\
(0.0082) \\
98.3 \% \\
\end{array}$ & $\begin{array}{c}0.0320 \\
(0.0080) \\
88.9 \% \\
\end{array}$ & $\begin{array}{c}0.0282 \\
(0.0074) \\
78.1 \% \\
\end{array}$ & $\begin{array}{c}0.0323 \\
(0.0076) \\
89.2 \% \\
\end{array}$ \\
\hline
\end{tabular}

Bootstrap standard errors (100 replications) in parentheses.

Data source: KfW Start-up Monitor, 2007. 
Table 5: Decomposition Analysis II: Relative Importance of Socio-Economics, Personality Traits, and a Base Effect

\begin{tabular}{|c|c|c|c|c|c|}
\hline \multirow{2}{*}{$\begin{array}{l}\text { Gender Difference } \\
\qquad \hat{Y}^{m}-\hat{Y}^{f}\end{array}$} & \multicolumn{2}{|c|}{ Characteristics Effect } & \multirow{2}{*}{$\begin{array}{c}\text { Base Effect } \\
\qquad 3\end{array}$} & \multicolumn{2}{|c|}{ Coefficients Effect } \\
\hline & $\begin{array}{c}\text { Socio-demographics } \\
\qquad \Delta 1\end{array}$ & $\begin{array}{l}\text { Personality } \\
\quad \Delta 2\end{array}$ & & $\begin{array}{c}\text { Personality } \\
\quad \Delta 4\end{array}$ & $\begin{array}{l}\text { Socio-demographics } \\
\Delta 5\end{array}$ \\
\hline 0.0362 & $\begin{array}{l}-0.0070 \\
(0.0044)\end{array}$ & $\begin{array}{c}0.0108 \\
(0.0018)\end{array}$ & $\begin{array}{l}-0.0195 \\
(0.0367)\end{array}$ & $\begin{array}{c}0.0103 \\
(0.0296)\end{array}$ & $\begin{array}{c}0.0415 \\
(0.0243)\end{array}$ \\
\hline $100.0 \%$ & $-19.3 \%$ & $29.9 \%$ & $-53.9 \%$ & $28.4 \%$ & $114.8 \%$ \\
\hline
\end{tabular}

Results of the preferred model with socio-demographics and personality traits.

Bootstrap standard errors (100 replications).

Data source: KfW Start-up Monitor, 2007. 